\title{
Evaluation of remote sensing based terrestrial productivity from MODIS using regional tower eddy flux network observations
}

Authors: Faith Ann Heinsch, Maosheng Zhao, Steven W. Running, John S. Kimball, Ramakrishna R. Nemani, Kenneth J. Davis, Paul V. Bolstad, Bruce D. Cook, Ankur R. Desai, Daniel M. Ricciuto, Beverly E. Law, Walter C. Oechel, Hyojung Kwon, Hongyan Luo, Steven C. Wofsy, Allison L. Dunn, J. William Munger, Dennis D. Baldocchi, Liukang Xu, David Y. Hollinger, Andrew D. Richardson, Paul C. Stoy, Mario B. S. Siqueira, Russell K. Monson, Sean P.

Burns, and Lawrence B. Flanagan

(c) 2006 IEEE. Personal use of this material is permitted. Permission from IEEE must be obtained for all other users, including reprinting/ republishing this material for advertising or promotional purposes, creating new collective works for resale or redistribution to servers or lists, or reuse of any copyrighted components of this work in other works. This was originally published in IEEE Transactions on Geoscience and Remote Sensing and can be found here, https://doi.org/10.1109/

\section{tgrs.2005.853936.}

Heinsch Faith A., Maosheng Zhao, Steven W. Running, John S. Kimball, Ramakrishna R. Nemani, Kenneth J. Davis, Paul V. Bolstad, Bruce D. Cook, Ankur R. Desai, Daniel M. Ricciuto, Beverly E. Law, Walter C. Oechel, Hyojung Kwon, Hongyan Luo, Steven C. Wofsy, Allison L. Dunn, J. William Munger, Dennis D. Baldocchi, Liukang Xu, David Y. Hollinger, Andrew D. Richardson, Paul C. Stoy, Mario B. S. Siqueira, Russell K. Monson, Sean P. Burns, and Lawrence B. Flanagan (2006) Evaluation of remote sensing based terrestrial productivity from MODIS using regional tower eddy flux network observations. IEEE Transactions on Geoscience and Remote Sensing 44: 1908-1925. DOI: 10.1109/TGRS.2005.853936. 


\title{
Evaluation of Remote Sensing Based Terrestrial Productivity From MODIS Using Regional Tower Eddy Flux Network Observations
}

\author{
Faith Ann Heinsch, Maosheng Zhao, Steven W. Running, John S. Kimball, Ramakrishna R. Nemani, \\ Kenneth J. Davis, Paul V. Bolstad, Bruce D. Cook, Ankur R. Desai, Daniel M. Ricciuto, Beverly E. Law, \\ Walter C. Oechel, Hyojung Kwon, Hongyan Luo, Steven C. Wofsy, Allison L. Dunn, J. William Munger, \\ Dennis D. Baldocchi, Liukang Xu, David Y. Hollinger, Andrew D. Richardson, Paul C. Stoy, Mario B. S. Siqueira, \\ Russell K. Monson, Sean P. Burns, and Lawrence B. Flanagan
}

\begin{abstract}
The Moderate Resolution Spectroradiometer (MODIS) sensor has provided near real-time estimates of gross primary production (GPP) since March 2000. We compare four years (2000 to 2003) of satellite-based calculations of GPP with tower eddy $\mathrm{CO}_{2}$ flux-based estimates across diverse land cover types and climate regimes. We examine the potential error contributions from meteorology, leaf area index (LAI)/fPAR, and land cover. The error between annual GPP computed from NASA's Data Assimilation Office's (DAO) and tower-based meteorology is $28 \%$, indicating that NASA's DAO global meteorology plays an important role in the accuracy of the GPP algorithm. Approximately $62 \%$ of MOD15-based estimates of LAI were within the estimates based on field optical measurements, although remaining values
\end{abstract}

Manuscript received October 1, 2004; revised April 25, 2005. This work was supported in part by the U.S. National Aeronautics and Space Administration (NASA) Earth Science Enterprise under MODIS Contract NAS5-31368. Eddy covariance flux tower sites are part of both the AmeriFlux and Fluxnet networks and are funded through a number of agencies, including the Department of Energy (DOE), the National Institute for Global Environmental Change (NIGEC), and NASA.

F. A. Heinsch, M. Zhao, S. W. Running, and J. S. Kimball are with The University of Montana, Missoula, MT 59812 USA (e-mail: faithann@ ntsg.umt.edu).

R. R. Nemani was with The University of Montana, Missoula, MT 59812 USA. He is now with NASA's Ames Research Center, Moffett Field, CA 94035 USA.

K. J. Davis, A. R. Desai, and D. M. Ricciuto are with The Pennsylvania State University, State College, PA 16804 USA.

P. V. Bolstad and B. D. Cook are with the University of Minnesota, St. Paul, MN 55108 USA.

B. E. Law is with Oregon State University, Corvallis, OR 97331 USA.

W. C. Oechel and H. Luo are with San Diego State University, San Diego, CA 92182 USA.

H. Kwon was with San Diego State University, San Diego, CA 92182 USA. She is now with The University of Wyoming, Laramie, WY 82071 USA.

S. C. Wofsy, A. L. Dunn, and J. W. Munger are with Harvard University, Cambridge, MA 02138 USA.

D. D. Baldocchi is with the University of California at Berkeley, Berkeley, CA 94720 USA.

L. Xu was with the University of California at Berkeley, Berkeley, CA 94720

USA. He is now with LI-COR Biosciences, Lincoln, NE 68504 USA.

D. Y. Hollinger is with the USDA Forest Service Northeast Research Station, Durham, NH 03824 USA.

A. D. Richardson is with the University of New Hampshire, Durham, $\mathrm{NH}$ 03824.

P. C. Stoy and M. B. S. Siqueira are with Duke University, Durham, NC 27708 USA.

R. K. Monson and S. P. Burns are with the University of Colorado, Boulder, CO 80309 USA.

L. B. Flanagan is with the University of Lethbridge, Lethbridge, AB T1K 3M4 Canada. overestimated site values. Land cover presented the fewest errors, with most errors within the forest classes, reducing potential error. Tower-based and MODIS estimates of annual GPP compare favorably for most biomes, although MODIS GPP overestimates tower-based calculations by 20\%-30\%. Seasonally, summer estimates of MODIS GPP are closest to tower data, and spring estimates are the worst, most likely the result of the relatively rapid onset of leaf-out. The results of this study indicate, however, that the current MODIS GPP algorithm shows reasonable spatial patterns and temporal variability across a diverse range of biomes and climate regimes. So, while continued efforts are needed to isolate particular problems in specific biomes, we are optimistic about the general quality of these data, and continuation of the MOD17 GPP product will likely provide a key component of global terrestrial ecosystem analysis, providing continuous weekly measurements of global vegetation production.

Index Terms-AmeriFlux, $\mathrm{CO}_{2}$ eddy covariance flux [net ecosystem exchange (NEE)], gross primary production (GPP), Moderate Resolution Imaging Spectroradiometer (MODIS), remote sensing, Terra.

\section{INTRODUCTION}

$\mathbf{G}$ LOBAL climate change is a topic of vital importance to meteorological and ecological science communities and policy makers. According to the IPCC [1], atmospheric carbon dioxide concentration has risen by $31 \%$ since 1750 , largely due to human activities such as fossil fuel burning and deforestation. Additionally, it is impossible to account for associated climate change, such as increases in air temperature without considering the effects of human activity on the carbon cycle [2]. However, atmospheric $\mathrm{CO}_{2}$ concentrations have not risen as high as expected once all of the known sources and sinks are taken into account [3]. It is hypothesized that much of this "missing" $\mathrm{CO}_{2}$ is being sequestered by terrestrial vegetation, and that the terrestrial biosphere, particularly mid-latitude forests, can sequester significant amounts of carbon [3]-[5]. While the magnitude of the net terrestrial carbon uptake is uncertain and varies interannually by a factor or two or more, the process of carbon sequestration correlates with global-scale climate variations [1], [5]-[7]. A scientific understanding of these processes in the context of the entire Earth system is important for the development of a sustainable life support system, and change in terrestrial biological activity is likely one of the "most fundamental 


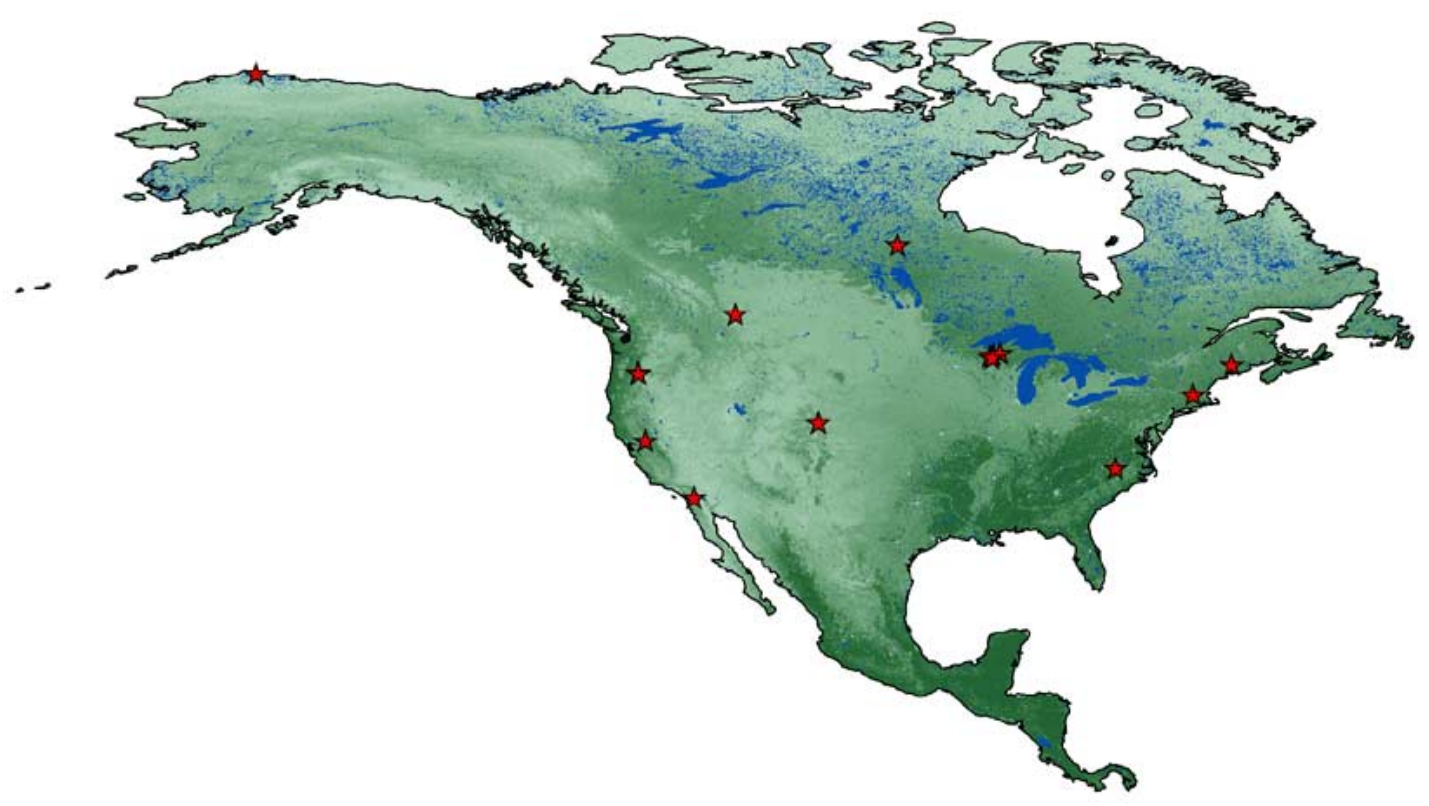

Fig. 1. Location of the AmeriFlux network sites used to verify the MODIS GPP product (projection = WGS 84; http://www.wgs84.com/).

measure[s] of global change" [8]. Approaching such an understanding at the global scale requires global measures of terrestrial biological activity. This interest has driven the effort to create a consistent, timely global dataset of primary production estimates.

Gross primary production (GPP) is a measure of photosynthesis and can be estimated from satellite remote sensing using optical and near-infrared spectral wavelengths [9]-[13]. Satellite remote sensing-based observations of GPP provide a quantitative, but inferred, measure of spatial patterns and seasonal to interannual variability in vegetation activity and can be used to assess relative human habitability of the biosphere in terms of the food, fiber, and fuel it provides. Additionally, GPP is the primary conduit of carbon flux from the atmosphere to land. Thus, improved knowledge of the spatial and temporal dynamics of GPP provides a useful measure of ecosystem health and impacts from regional disturbances from land use and climate change, resulting in a better understanding of the carbon cycle [11], [14].

The Moderate Resolution Imaging Spectrometer (MODIS) was designed in part to help answer questions about global carbon dynamics. Mounted on both the Terra and Aqua satellites of the Earth Observing System (EOS), the MODIS sensors provide near daily coverage of the globe at $1-\mathrm{km}$ resolution. From the 36 spectral bands present on the sensor, a number of products have been developed for the atmosphere, ocean, and land surface. Our particular interest is the use of the MODIS sensor to estimate GPP at a $1-\mathrm{km}$ resolution for 109782756 $\mathrm{km}^{2}$ of global vegetated land surface. Satellite remote sensing measurements of GPP are inferred from surface reflectance measurements made from space, and they are only useful if their relative accuracy can be determined. A number of verification efforts have been established to determine the accuracy of the MODIS standard products. The BigFoot validation project, for example, has provided detailed information regarding spatial scale attributes of a number of biophysical variables produced from MODIS including: land cover class, leaf area index (LAI), and the associated fraction of photosynthetically active radiation absorbed by vegetation canopies (fPAR) and vegetation net primary production (NPP) at a few sites throughout North America [15]-[17]. However, these intensive sampling and validation efforts were relatively infrequent in space and time due to their high cost and logistical constraints. For this investigation, we evaluate regional patterns and temporal dynamics of satellite remote sensing estimates of seasonal and annual GPP from MODIS using more limited information from a greater number of sites within various biomes and climate regimes. Our effort is aimed at determining if there is a systematic bias in MODIS production estimates relative to network observation-based GPP estimates, and if such a bias originates from the MODIS input data. Specifically, we compare flux tower-based estimates of GPP to MODIS-based estimates at fifteen research sites in six different biome classes across North America (Fig. 1; Table I).

The calculation of GPP used in the MODIS GPP algorithm (MOD17; Fig. 2) is based on work done by Monteith [18], [19] relating gross photosynthesis to the amount of photosynthetically active radiation (PAR) absorbed by photosynthetic biomass. A conversion efficiency term is used in the relationship, such that

$$
\mathrm{GPP}=\varepsilon \times \mathrm{fPAR} \times \mathrm{PAR}
$$

where $\varepsilon$ is the radiation use conversion efficiency (RUE) of the vegetation $\left(\mathrm{kgC} \cdot \mathrm{MJ}^{-1}\right), \mathrm{fPAR}$ is the fraction of incident PAR that is absorbed by the canopy, and PAR is the PAR attendant on the canopy $\left(\mathrm{MJ} \cdot \mathrm{d}^{-1}\right)$.

The RUE (i.e., the amount of carbon a specific vegetation type can produce per unit of energy $\varepsilon$ ) is calculated as

$$
\varepsilon=\varepsilon_{\max } \times m\left(T_{\min }\right) \times m(\mathrm{VPD})
$$

where $\varepsilon_{\max }$ is the biome-specific maximum conversion efficiency, $m\left(T_{\min }\right)$ is a multiplier that reduces the conversion efficiency when cold temperatures limit plant function, and 
TABLE I

AMERIFlux NeTwork Sites USEd IN ANALYsis

\begin{tabular}{|c|c|c|c|c|c|c|}
\hline Site Name & Latitude, Longitude & $\begin{array}{c}\text { Elevation } \\
(\mathrm{m})\end{array}$ & $\begin{array}{l}\text { Biome } \\
\text { Type }\end{array}$ & $\begin{array}{l}\text { GPP Data: } \\
\text { Years, Source }\end{array}$ & $\begin{array}{c}\text { Related } \\
\text { Publications }\end{array}$ & $\begin{array}{c}\text { Principal } \\
\text { Investigator(s) }\end{array}$ \\
\hline Barrow, Alaska, USA & $71.1436^{\circ} \mathrm{N}, 155.6264^{\circ} \mathrm{W}$ & 1 & Tundra $^{1}$ & 2001, calculated ${ }^{5}$ & N/A & W.C. Oechel \\
\hline Duke Forest, North Carolina, USA & $35.9781^{\circ} \mathrm{N}, 79.0941^{\circ} \mathrm{W}$ & 163 & $\mathrm{ENF}^{2}$ & 2001-2003, calculated ${ }^{6}$ & $\begin{array}{l}\text { Desai et al. [36], } \\
\text { Schäfer et al. }[59]\end{array}$ & G.G. Katul \\
\hline $\begin{array}{l}\text { Harvard Forest, Massachusetts, } \\
\text { USA }\end{array}$ & $42.5357^{\circ} \mathrm{N}, 72.1719^{\circ} \mathrm{W}$ & 340 & $\mathrm{DBF}^{3}$ & 2001-2002, $\mathrm{PI}^{7}$ & $\begin{array}{l}\text { Wofsy et al. [4], } \\
\text { Barford et al. }\end{array}$ & $\begin{array}{l}\text { S.C. Wofsy, } \\
\text { J.W. Munger }\end{array}$ \\
\hline Howland Forest, Maine, USA & $45.2042^{\circ} \mathrm{N}, 68.7403^{\circ} \mathrm{W}$ & 60 & $\mathrm{ENF}$ & 2000-2003, PI $^{7}$ & $\begin{array}{l}\text { Hollinger et al. [60], } \\
\text { Hollinger et al. }[61]\end{array}$ & D.Y. Hollinger \\
\hline Lethbridge, Alberta, Canada & $49.7092^{\circ} \mathrm{N}, 112.9400^{\circ} \mathrm{W}$ & 960 & Grassland & $2000-2001$, PI $^{7}$ & $\begin{array}{c}\text { Flanagan et al. [62], } \\
\text { Wever et al. }[63]\end{array}$ & L.B. Flanagan \\
\hline Lost Creek, Wisconsin, USA & $46.0826^{\circ} \mathrm{N}, 89.9791^{\circ} \mathrm{W}$ & 480 & $\mathrm{DBF}$ & 2000-2003, $\mathrm{PI}^{7}$ & N/A & P.V. Bolstad \\
\hline Metolius - Old Site, Oregon, USA & $44.4991^{\circ} \mathrm{N}, 121.6220^{\circ} \mathrm{W}$ & 915 & $\mathrm{ENF}$ & $2001, \mathrm{PI}^{7}$ & $\begin{array}{l}\text { Anthoni et al. [64], } \\
\text { Law et al. }[65]\end{array}$ & B.E. Law \\
\hline $\begin{array}{l}\text { Metolius - Young Site, Oregon, } \\
\text { USA }\end{array}$ & $44.4371^{\circ} \mathrm{N}, 121.5660^{\circ} \mathrm{W}$ & 1188 & ENF & $2001, \mathrm{PI}^{7}$ & $\begin{array}{l}\text { Anthoni et al. }[64] \\
\text { Law et al. }[65]\end{array}$ & B.E. Law \\
\hline Niwot Ridge, Colorado, USA & $40.0328^{\circ} \mathrm{N}, 105.5460^{\circ} \mathrm{W}$ & 3050 & ENF & 2001-2002, calculated ${ }^{5}$ & $\begin{array}{l}\text { Monson et al. [66], } \\
\text { Turnipseed et al. [67] }\end{array}$ & $\begin{array}{l}\text { R.K. Monson, } \\
\text { A.A. Turnipseed }\end{array}$ \\
\hline $\begin{array}{l}\text { BOREAS Northern Old Black } \\
\text { Spruce, Saskatchewan, Canada }\end{array}$ & $55.8801^{\circ} \mathrm{N}, 98.4814^{\circ} \mathrm{W}$ & 239 & ENF & $2000-2003, \mathrm{PI}^{7}$ & $\begin{array}{l}\text { Goulden et al. [68], } \\
\text { Gouldnet } \text { et al. [69] }\end{array}$ & S.C. Wofsy \\
\hline $\begin{array}{l}\text { WLEF, Park Falls, Wisconsin, } \\
\text { USA }\end{array}$ & $45.9458^{\circ} \mathrm{N}, 90.2723^{\circ} \mathrm{W}$ & 470 & Mixed Forest & $2000-2002, \mathrm{PI}^{7}$ & $\begin{array}{l}\text { Davis et al. [70], } \\
\text { Berger et al. }\end{array}$ & K.J. Davis \\
\hline $\begin{array}{l}\text { Sky Oaks - Old Site, California, } \\
\text { USA }\end{array}$ & $33.3738^{\circ} \mathrm{N}, 116.6220^{\circ} \mathrm{W}$ & 1407 & Chaparral $^{4}$ & 2001 , calculated ${ }^{5}$ & Luo et al. [71] & W.C. Oechel \\
\hline $\begin{array}{l}\text { Sylvania Wilderness Area, } \\
\text { Michigan, USA }\end{array}$ & $46.2420^{\circ} \mathrm{N}, 89.3476^{\circ} \mathrm{W}$ & 540 & Mixed Forest & $2002-2003, \mathrm{PI}^{7}$ & Desai et al. [36] & P.V. Bolstad \\
\hline Tonzi Ranch, California, USA & $38.4316^{\circ} \mathrm{N}, 120.9650^{\circ} \mathrm{W}$ & 129 & Oak Savanna & $2001-2003, \mathrm{PI}^{7}$ & Baldocchi et al. [72] & D.D. Baldocchi \\
\hline Willow Creek, Wisconsin, USA & $45.8050^{\circ} \mathrm{N}, 90.0793^{\circ} \mathrm{W}$ & 520 & $\mathrm{DBF}$ & $2000-2003, \mathrm{PI}^{7}$ & $\begin{array}{l}\text { Cook et al. [37], } \\
\text { Desai et al. [36] }\end{array}$ & $\begin{array}{l}\text { P.V. Bolstad, } \\
\text { K.J. Davis }\end{array}$ \\
\hline
\end{tabular}

${ }^{1}$ Tundra modeled as a Grassland

${ }^{2}$ ENF $=$ Evergreen Needleleaf Forest

${ }^{3} \mathrm{DBF}=$ Deciduous Broadleaf Fores

${ }^{4}$ Chaparral modeled as Open Shrubland

${ }^{5}$ Component fluxes calculated using the method by Reichstein et al., 2002

${ }^{6}$ Component fluxes calculated using the method by Cook et al., 2004 and Desai et al., 2005

${ }^{7}$ Site specific component fluxes provided by Principal Investigators

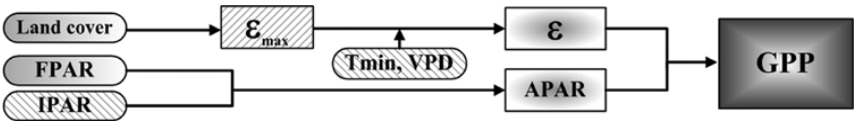

Fig. 2. Flowchart shows the logic behind the MOD17 algorithm for calculating eight-day GPP.

$m(\mathrm{VPD})$ is a multiplier used to reduce the maximum conversion efficiency when the vapor pressure deficit (VPD) is high enough to inhibit photosynthesis. The multipliers range linearly from 0 (total inhibition) to 1 (no inhibition) for a range of biomes, which are listed in a Biome Properties Look-Up Table (BPLUT), along with the biome-specific maximum conversion efficiency used in the algorithm [20]. The effect of soil water availability is not included in the GPP algorithm. To partially account for this issue, sensitivity to VPD is increased in the model as a surrogate for drought effects. Complete details on the derivation of the algorithm and the values used in the BPLUT can be found elsewhere [20]-[22].

There are three potential sources of error related to inputs for the MOD17 GPP algorithm: 1) meteorology, 2) radiometry, and 3 ) biophysical inputs to the model. Each of these sources of error requires a different mode of verification and must be considered separately. Meteorological errors arise from the use of global scale meteorology $\left(1.00^{\circ} \times 1.25^{\circ}\right)$ from NASA's Data Assimilation Office (DAO) GEOS-4 global climate model. Errors in the radiometry derive from results of the MODIS LAI/fPAR algorithm (MOD15) [23]-[25]. There are two potential sources of error regarding biophysical attributes. Correct land cover classification from the MOD12 decision tree algorithm is vital to the success of MODIS GPP calculations. The fPAR algorithm uses a structural land cover classification scheme in its calculations [24], while the GPP algorithm depends upon the University of Maryland (UMD) land cover classification scheme [26] to differentiate among biome types and determine the correct conversion efficiency for the pixel. Errors in either of these classification schemes will lead to incorrect estimates of production.

Additional sources of potential error arise from the biomespecific properties used in the MOD17 algorithm. An accurate derivation of $\varepsilon$ is difficult because it is affected both by variations in climate (e.g., temperature, humidity, and soil water) and by biological attributes (e.g., land cover type $\mathrm{C}_{3}$ versus $\mathrm{C}_{4}$ plants) [8]. To implement MOD17 globally, assumptions are made to establish a single use efficiency for each of the 12 land cover classes used in the MOD17 algorithm. These biomespecific radiation-use efficiencies, as well as the stress limits for minimum temperature and VPD, were originally derived prelaunch using a global simulation of the ecosystem process model Biome-BGC [27]-[29]. Postlaunch verification efforts have led to a recalibration of these parameters in the latest version of MOD17, described fully by Zhao et al. [30]. The recalibration has resulted in a new release of the MOD17 data 
(Collection 4.5; C4.5), which is the basis for this investigation. Finally, we assume that nutrient constraints on vegetation growth such as nitrogen stress are quantified by limiting canopy leaf area. While this assumption is not entirely accurate [31], spectral reflectances are somewhat sensitive to leaf chemistry, and MODIS-derived LAI and fPAR may partially assess differences in leaf nitrogen content.

\section{MATERIALS AND MethodS}

This investigation focuses on error contributions from meteorology, land cover, and the MOD15 LAI/fPAR algorithm only. Additional error sources may be due to uncertainties in the ecophysiological assumptions of the BPLUT, but these require further investigation.

\section{A. Meteorological Data}

Site meteorological data were obtained directly from participating site researchers or were downloaded from the AmeriFlux network website (public.ornl.gov/ameriflux). Half-hourly or hourly data consisting of air temperature (Tair, ${ }^{\circ} \mathrm{C}$ ); precipitation (PPT, $\mathrm{cm})$; either PAR $\left(\mu \mathrm{mol} \cdot \mathrm{m}^{-2} \cdot \mathrm{s}^{-1}\right)$ or incoming shortwave radiation (SWRad, $\mathrm{W} \cdot \mathrm{m}^{-2}$ ); and either relative humidity (RH, \%) or VPD, Pa were used in this analysis. From these data, we obtained daily maximum air temperature $\left(\mathrm{T}_{\max }\right.$, $\left.{ }^{\circ} \mathrm{C}\right)$, minimum air temperature $\left(\mathrm{T}_{\min },{ }^{\circ} \mathrm{C}\right)$, average daytime temperature (Tday, ${ }^{\circ} \mathrm{C}$ ), daytime average VPD (VPDavg, $\mathrm{Pa}$ ), and total SWRad (assuming PAR $=0.45 \times \mathrm{SWRad}$, $\left.\mathrm{MJ} \cdot \mathrm{m}^{-2} \cdot \mathrm{d}^{-1}\right)$.

Direct inputs to the MODIS GPP algorithm include Tday, $\mathrm{T}_{\min }$, VPDavg, and SWRad, which were obtained from NASA's Data Assimilation Office (DAO, polar.gsfc.nasa.gov) GEOS-4 global climate model at a $1.00^{\circ} \times 1.25^{\circ}$ resolution [32], [33]. Daily data for each pixel were first compiled from three-hour data and then interpolated using a nonlinear interpolation scheme based on the four nearest DAO cells [30].

\section{B. Eddy Covariance $\mathrm{CO}_{2}$ Flux and Site Data}

For this effort, we relied heavily upon members of the AmeriFlux community to provide ground-based measurements of the net ecosystem exchange (NEE) of $\mathrm{CO}_{2}$ between the biosphere and the atmosphere, as well as LAI measurements and vegetation cover types. The NEE measurements are used with local meteorological measurements to estimate GPP for fifteen individual sites (38 site years) in North America (Table I). AmeriFlux is a regional network of sites making micrometeorological, meteorological and biological measurements in different biomes of North and South America [34]. To ascertain the quality of a global product, it is necessary to verify the product under many different scenarios, in this case, differing vegetation types and climate regimes. Many of the selected sites are forest ecosystems with widely disparate climate. A number of these forests are boreal and transitional forests of diverse species composition, including hardwoods, conifers and mixed forest with dissimilar soils and hydrologic patterns. Other forests include a subalpine forest and a warm-temperate planted pine forest. Additional biomes represented in this study include artic tundra, northern grassland, oak savanna, and chaparral. Climate regimes range from the northern arctic to mid-continent boreal and transition areas, as well as temperate and Mediterranean climates.

Available NEE estimates were obtained for the years 2000 to 2003 (Table I). Many site investigators provided site-specific estimates of the component fluxes [GPP and ecosystem respiration (Reco)]. GPP and Reco were estimated for several additional sites using a method that accounts for seasonal changes in the temperature sensitivity of ecosystem respiration using NEE, canopy $\mathrm{CO}_{2}$ storage, air and soil temperatures, VPD, and incoming shortwave radiation [35]. Estimates of GPP and Reco for the Duke Forest site were obtained using the method created for the Chequamegon Ecosystem Atmosphere Study (ChEAS) study sites (WLEF, Lost Creek, Sylvania, Willow Creek) [36], [37]. This method is a slight modification of the method used by Falge et al. [38], and Reco and GPP are modeled using response functions based on soil temperature and PAR.

Site-specific LAI data were obtained from the literature, the AmeriFlux website, and site investigators. In general, only average maximum LAI measurements were available for the sites. Where possible, annual measurements corresponding to the time of the MODIS estimates were obtained. Otherwise, multiyear means were calculated from available data, representing typical values for each site. While spatial heterogeneity within a 1-km MODIS cell is common [15], it is not specifically tested in this study because of the large number of sites and limited datasets available.

\section{MODIS Data}

The verification exercise is based on Collection 4.5 (C4.5) MODIS GPP (MOD17) data, available from the NTSG anonymous ftp site (ftp.ntsg.umt.edu/pub/MODIS). Using the latitude and longitude provided by the investigators, ASCII subsets for many of the MODIS land products are created at the Oak Ridge National Laboratory (ORNL) Distributed Active Archive Center (DAAC) (www.modis.ornl.gov/modis/index.cfm). We obtained $7 \times 7 \mathrm{~km}$ cutouts centered over each eddy covariance flux tower location representing:

1) land cover classification (MOD12Q1, C3);

2) LAI and fraction of absorbed PAR (fPAR) (MOD15A2, C4);

3) GPP (MOD17A2, C4.5).

The MODIS Collection 3 (C3) land cover classification [39] is used in the Collection 4 (C4) LAI/fPAR and Collection 4.5 (C4.5) MODIS GPP calculations. While the Collection 4 land cover dataset has been recently released and is a significant improvement over the Collection 3 (C3) dataset [40], this analysis is restricted to the $\mathrm{C} 3 \mathrm{MOD} 12$ land cover classification dataset. There are two separate land cover classification schemes used in the calculation of GPP. First, the MOD15 (LAI/fPAR) algorithm uses the MOD12Q1 Land Cover Classification Type 3 (LAI/fPAR biome scheme) [24], [41]. The MOD17 algorithm uses the University of Maryland (UMD) land cover classification (MOD12Q1 Land Cover Classification Type 2 [26]). Errors in classifying either or both of these land cover types will propagate to the MOD17 algorithm, resulting in erroneous GPP outputs. 
The MOD15A2 LAI and fPAR data were subjected to a rigorous quality check in which only those pixels that were of good quality according to the MOD15A2 quality assurance product and that used the primary radiative transfer algorithm were accepted [25]. Average eight-day LAI and fPAR were calculated separately for each land cover type found within a $7 \times 7 \mathrm{~km}$ grid. Linear interpolation was used to fill data gaps in the LAI and fPAR as in the official C4.5 product [30]. Eight-day mean, total seasonal, and total annual values of GPP were calculated for each $7 \times 7 \mathrm{~km}$ subset (49 pixels) and used for comparison with site estimates of GPP. MODIS data collection began on Day 56 of 2000. Therefore, to have four complete years of data, average LAI and fPAR were calculated from the 2001 to 2003 data and used to simulate GPP estimates for January-February 2000.

Gaps within the MOD15 LAI and fPAR data were filled via linear interpolation. An average of $15( \pm 8)$ eight-day averages (out of a possible 46) were missing during each site year with a median gap size of $6(\max =20$ at Barrow, $\mathrm{AK} ; \min =2$ at numerous sites). During March 30-October 15, there were an average of six $( \pm 4)$ missing datapoints with a median gap size of 2 ( $\max =10$ at Harvard Forest; $\min =0$ at Lethbridge).

Once the data were compiled, we made direct comparisons of both total annual and seasonal MOD17 GPP with tower-estimated GPP. To elucidate the effects of meteorology on the results, we used an off-line, but identical, version of the MOD17 GPP algorithm to calculate the GPP for each of the land cover types at each site using the DAO meteorology and the land-cover specific average fPAR mentioned in the previous paragraph. We then created weighted averages of GPP for each site year. We replaced the DAO meteorology with tower meteorology and followed the same procedure to obtain estimates of GPP based on the local site environment. Use of the off-line algorithm ensured that the only variant in the input data was the meteorology.

\section{Analytical Methods}

All datasets were tested for normality using the ShapiroWilkes normality test. Pearson's correlation analysis (r) was used when the data were normal, and the confidence limits (CL) surrounding $\mathrm{r}$ were calculated as

$$
\mathrm{CL}=\sqrt{\frac{1-r^{2}}{n-2}} \times t_{\alpha / 2, d f}
$$

where $n$ is the number of samples used in the analysis and $t$ is the Student t-statistic. When the data were not normally distributed, a paired two-sided t-test was used, as it is more robust to the assumption of normality. In both cases, data were considered statistically significant when $p \leq 0.05$. When data were subset, such as the biome-specific data, a Bonferroni correction was applied, and data were considered statistically significant when $p \leq 0.0975$. Finally, a relative error term (RE, \%) was calculated for each comparison, such that

$$
\mathrm{RE}=\frac{\sum_{i=1}^{n}\left(\frac{\text { MODIS GPP }_{i}-\text { Tower GPP }_{i}}{\text { Tower GPP }_{i}}\right)}{n} \times 100 .
$$

\section{RESULTS}

\section{A. Annual GPP (MOD17, C4.5)}

The most recent release of MOD17 data (C4.5) was compared with flux tower estimates of annual GPP (Table II). There is a fairly strong correlation between the MOD17 standard product and tower estimates of annual GPP ( $\mathrm{r}=0.859 \pm 0.173)$, but MOD17 tends to overestimate tower GPP for most sites (RE = $24 \%$ ). For the most productive sites, however, MOD17 underestimates tower GPP. Potential errors associated with the MOD17 algorithm were described in the introduction and are covered individually as follows.

\section{B. Meteorology (DAO)}

The NASA DAO global meteorology used with MODIS spectral data to derive GPP is obtained at relatively coarse $\left(1.00^{\circ} \times 1.25^{\circ}\right)$ spatial scales. The DAO-based MOD17 algorithm results (DAO-based GPP), using the off-line calculations of fPAR, produced an mean annual GPP of $1039 \mathrm{gC} \cdot \mathrm{m}^{-2} \cdot \mathrm{d}^{-1}$ [Fig. 3(a); Table II], nearly identical to results from the standard product. Differences are attributed to the averaging technique used in the analysis. The remaining comparisons in this paper will be made against these data as they are directly comparable to calculations made with tower meteorology. These results also have good correlation with annual tower GPP (996 $\left.\mathrm{gC} \cdot \mathrm{m}^{-2} \cdot \mathrm{d}^{-1} ; \mathrm{r}=0.855 \pm 0.175\right)$. The DAO-based data consistently overestimated local tower-based estimates, with a relative error of $19 \%$. Use of local tower meteorology in the MOD17 algorithm [Fig. 3(b); Table II] reduced correlation when compared with tower network-based GPP results ( $r=0.792 \pm 0.206)$, but also reduced RE $(-2 \%)$. Underestimation of tower GPP increased at the most productive site (Duke Forest), indicating that there are several factors affecting GPP estimates at this site.

Overall, the arithmetic mean difference between DAO and tower meteorology based GPP results is $28 \% \pm 45 \%$, indicating that the DAO meteorology plays an important role in the accuracy of the GPP algorithm, and that this role is site specific (Fig. 4). Minimum daily temperatures are significantly different from local measurements at both the Tonzi Ranch site $(p<0.001)$ and the Niwot Ridge site $(p<0.001)$. On an annual basis, minimum daily temperatures are overestimated at the Tonzi Ranch site $(\mathrm{RE}=30 \%)$ and underestimated at the Niwot Ridge site $(\mathrm{RE}=-25 \%)$. The mean annual daytime VPD is generally underestimated by the DAO meteorology [Fig. 4(c) and (f)] at both Niwot Ridge, the humid subalpine site $(p<0.001)$, and dry sites, such as Metolius and Tonzi Ranch $(p<0.001)$, although this trend is more apparent at the dry sites, particularly during the summer months [Summer RE $=-28 \%$; Fig. 4(f)]. Radiation tends to be well represented, but localized cloud cover results in substantial day-to-day variability in the results, which can cause significant discrepancies between the DAO and tower meteorology at both sites $(p<0.001)$. Variability in radiation is greater at the Tonzi Ranch site $(\mathrm{RE}=32 \%)$ than the Niwot Ridge site $(\mathrm{RE}=3 \%)$.

The effect of meteorology varies by biome type and site (Figs. 1 and 3 and Table III). There are only two biomes as classified by the C3 MOD12 land cover classification with 
TABLE II

COMPARISON OF TOWER Estimates OF GPP WITH THOSE DERIVED From THE MODIS ALGORITHM

\begin{tabular}{|c|c|c|c|c|c|c|c|}
\hline Comparison & $\mathbf{n}$ & $\begin{array}{l}\text { Tower Mean (SD) } \\
\qquad\left(\mathrm{gC} \mathrm{m}^{-2} \mathrm{y}^{-1}\right)\end{array}$ & $\begin{array}{l}\text { MODIS Mean (SD) } \\
\qquad\left(\mathrm{gC} \mathrm{m}^{-2} \mathrm{y}^{-1}\right)\end{array}$ & $\mathbf{r} \pm \mathbf{C} \mathbf{L}^{1}$ & t-statistic ${ }^{2}$ & p-value ${ }^{3}$ & $\begin{array}{c}\text { Relative Error } \\
(\%)\end{array}$ \\
\hline Annual & 38 & & & & & & \\
\hline MODIS GPP (C4.5) vs. Tower GPP - Standard Product & & $996(549)$ & $1058(374)$ & $0.859 \pm 0.173$ & & & 24 \\
\hline MODIS GPP with DAO Meteorology vs. Tower GPP & & $996(549)$ & $1039(370)$ & $0.855 \pm 0.175$ & & & 19 \\
\hline MODIS GPP with Tower Meteorology vs. Tower GPP & & $996(549)$ & $869(364)$ & $0.792 \pm 0.206$ & & & -2 \\
\hline Seasonal & 38 & & & & & & \\
\hline \multicolumn{8}{|l|}{ Spring (Mar - May) } \\
\hline MODIS GPP with DAO Meteorology vs. Tower GPP & & $201(170)$ & $257(124)$ & & 8.759 & $<0.0001$ & 84 \\
\hline MODIS GPP with Tower Metcorology vs. Tower GPP & & $201(170)$ & $208(93)$ & & 6.926 & $<0.0001$ & 50 \\
\hline \multicolumn{8}{|l|}{ Summer (Jun - Aug) } \\
\hline MODIS GPP with DAO Meteorology vs. Tower GPP & & $568(306)$ & $568(201)$ & & 10.065 & $<0.0001$ & 38 \\
\hline MODIS GPP with Tower Meteorology vs. Tower GPP & & $568(306)$ & $469(236)$ & & 6.290 & $<0.0001$ & -4 \\
\hline \multicolumn{8}{|l|}{ Autumn (Sep - Nov) } \\
\hline MODIS GPP with DAO Meteorology vs. Tower GPP & & $181(139)$ & $202(92)$ & $0.800 \pm 0.203$ & & & 69 \\
\hline MODIS GPP with Tower Meteorology vs. Tower GPP & & $181(139)$ & $175(91)$ & & 7.939 & $<0.0001$ & 38 \\
\hline \multicolumn{8}{|l|}{ Winter (Jan - Feb, Dec) } \\
\hline MODIS GPP with DAO Meteorology vs. Tower GPP & & $36(66)$ & $36(50)$ & $0.819 \pm 0.194$ & & & 357 \\
\hline MODIS GPP with Tower Meteorology vs. Tower GPP & & $36(66)$ & $29(41)$ & $0.746 \pm 0.225$ & & & 357 \\
\hline
\end{tabular}

sufficient data for significant statistical analysis-evergreen needleleaf forests (ENF) and mixed forests (MF). The evergreen needleleaf forest sites cover a range of biomes, including boreal, subalpine, and dry temperate areas. The MODIS GPP with DAO meteorology significantly overestimates tower GPP at all of these sites $(p=0.060 ; \mathrm{RE}=23 \%)$. Use of tower meteorology leads to a significant underestimation of annual $\operatorname{GPP}(p=0.027 ; \mathrm{RE}=-6 \%)$.

The MOD17 algorithm GPP for MF sites is significantly different from the tower GPP for calculations using both DAO meteorology $(p<0.001)$ and tower meteorology $(p<0.001)$ (Table III). However, annual relative error for both datasets is small ( $\mathrm{RE}=10 \%$ and $-2 \%$, respectively). This analysis fails to illustrate that there is, in fact, little variation in the MODIS estimates of GPP regardless of the value of the tower GPP (Fig. 3). At the most productive site (Duke Forest), MODIS substantially underestimates GPP (mean RE $=-19 \%$ for DAO and $\mathrm{RE}=-40 \%$ for tower meteorology), noting that Duke forest, an ENF, is misclassified as MF (see Section III-C).

The relationships between MODIS and tower estimates at the Duke Forest and Tonzi Ranch sites become worse when tower data are used. Use of the DAO meteorology in the MODIS GPP algorithm at the Duke Forest site results in GPP values that are consistently lower than tower-based results for all four years examined ( $\mathrm{RE}=-20 \%)$. The use of tower meteorology lowers GPP estimates even further $(\mathrm{RE}=-38 \%)$. At the Tonzi Ranch site, DAO meteorology leads to an overestimate of GPP $(\mathrm{RE}=29 \%$ ), while tower meteorology leads to a much larger underestimation of GPP ( $\mathrm{RE}=-46 \%)$.
There is an underestimation of GPP using both DAO (RE = $-20 \%)$ and tower meteorology $(\mathrm{RE}=-24 \%)$ for the Harvard Forest site, identified by the MODIS UMD land cover classification as the only predominately deciduous broadleaf forest. Open shrubland (OS) sites are overestimated when local tower meteorology is used in the MODIS GPP algorithm $(\mathrm{RE}=67 \%)$, but there is greater GPP overestimation when DAO meteorology is used $(\mathrm{RE}=108 \%)$. There is a general reduction in MODIS GPP when local tower meteorology is used at the savanna site ( $\mathrm{RE}=-46 \%$ ), while the DAO based meteorology tends to overestimate GPP ( $\mathrm{RE}=30 \%)$. There is no major change in the relationship between tower- and MODIS-based GPP at the Lethbridge grassland site with the change in meteorology, indicating that the use of DAO meteorological data accurately captures annual GPP (RE $=4 \%$; Table III).

All of the temperate-boreal transitional forest sites (Lost Creek, WLEF, Willow Creek, Sylvania, Howland Forest) have approximately the same MODIS-derived GPP $\left(1180 \pm 60 \mathrm{gC} \cdot \mathrm{m}^{-2} \cdot \mathrm{d}^{-1}\right)$, although tower GPP is actually quite variable, ranging from 660 to $1450 \mathrm{gC} \cdot \mathrm{m}^{-2} \cdot \mathrm{d}^{-1}$. Four of these five study sites are part of a local cluster of towers situated in close proximity to one other. They are also located within the same DAO grid cell, and the tower meteorology at these four sites is quite similar. Although tower estimates of the MOD17 algorithm accurately reflect GPP at the Willow Creek and Sylvania sites, GPP at the Lost Creek and WLEF sites is overestimated. The GPP of the Howland Forest site is underestimated when compared with tower data. When tower 

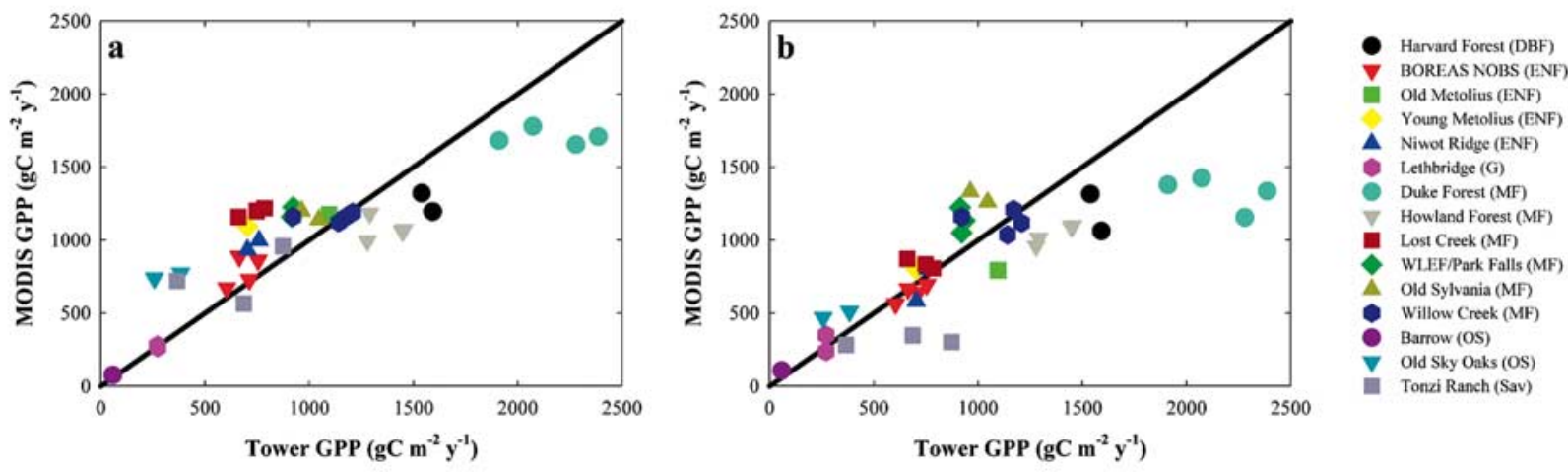

Fig. 3. Comparison of annual GPP estimates from the flux tower sites and the MODIS $7 \times 7 \mathrm{~km}$ cutout. These data were created using (a) the global DAO meteorology and (b) tower-specific meteorology.

Minimum Temperature $\left({ }^{\circ} \mathrm{C}\right)$

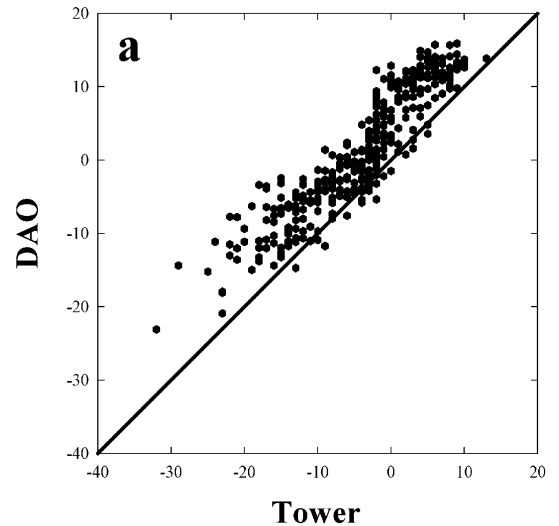

Minimum Temperature $\left({ }^{\circ} \mathrm{C}\right)$

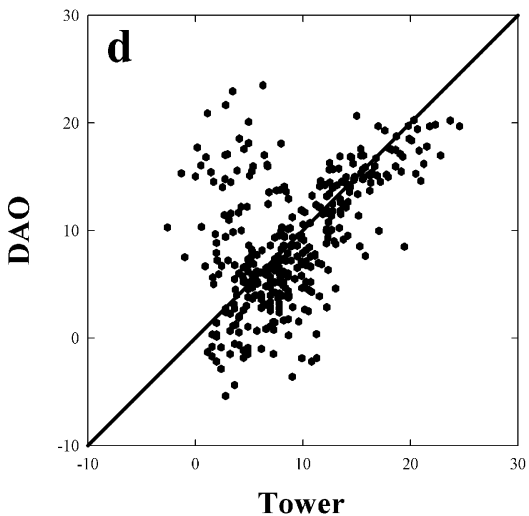

Vapor Pressure Deficit (Pa)

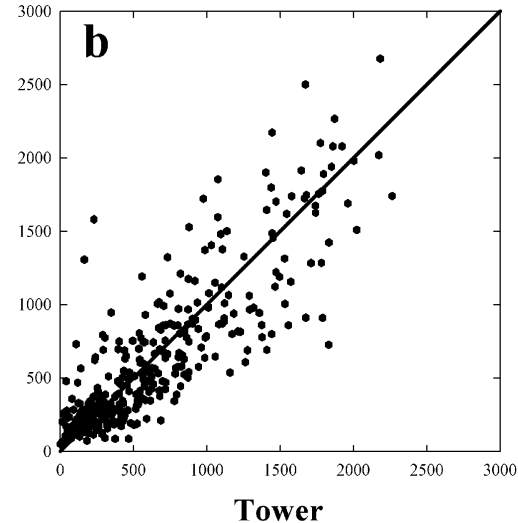

Vapor Pressure Deficit $(\mathrm{Pa})$

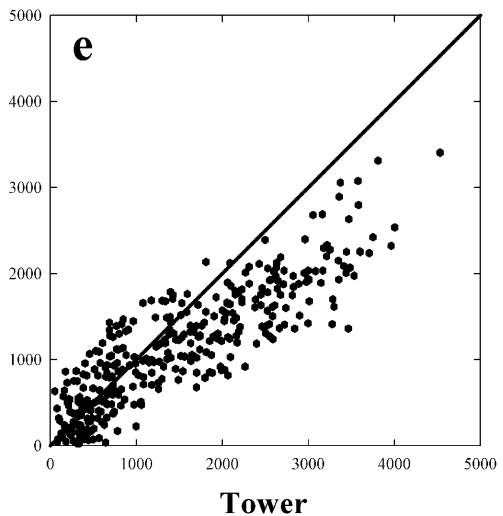

$\operatorname{PAR}\left(\right.$ MJ m ${ }^{-2} \mathrm{~d}^{-1}$ )

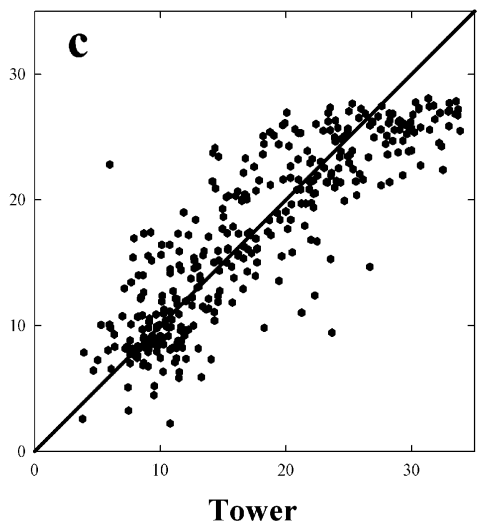

PAR (MJ m ${ }^{-2} \mathrm{~d}^{-1}$ )

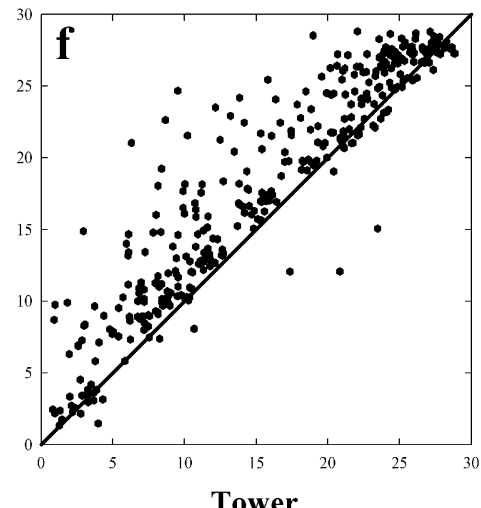

Fig. 4. Comparison of the VPD measured at the tower site and that estimated by the global DAO meteorology for 2002. Sites with both (a)-(c) low summer daytime average VPD (Niwot Ridge) and (d)-(f) high summer daytime average VPD (Tonzi Ranch) are shown. These two sites reflect the extremes in summertime VPD measured at the study sites.

meteorology is used in the MODIS algorithm, the comparison between tower and MODIS GPP improves.

\section{Land Cover (MOD12)}

Forested ecosystems are the dominant biomes considered in this verification exercise (Table II). In general, the MOD12 decision tree algorithm classifies forests correctly (Fig. 5). Most errors that do occur are within the forest classes. For example, many pixels are classified as mixed forest (MF) pixels when they are actually dominated by either evergreen needleleaf forest
(ENF) or deciduous broadleaf forest (DBF). The underlying LAI/fPAR land cover classification more accurately reflects the vegetation cover (data not shown), presumably because there is no mixed forest classification within the LAI/fPAR land cover scheme [24], [26].

There are some areas in which misclassification may be a significant source of error (Fig. 5). At the Barrow tower site, for example, local vegetation is predominantly wet sedge tundra, which is more physiologically similar to grassland (Class 10) than the shrubland (Class 7) and barren/sparse vegetation 
TABLE III

BIOME-BASED COMPARISON OF TOWER ESTIMATES AND MODIS-DERIVED ESTIMATES OF ANNUAL GPP Using (A) Global Meteorology AND (B) Tower Meteorology IN THE MODIS Algorithm

\begin{tabular}{|c|c|c|c|c|c|c|}
\hline Comparison & n & $\begin{array}{c}\text { Tower Mean (SD) } \\
\left(\mathrm{gC} \mathrm{m}^{-2} \mathrm{y}^{-1}\right)\end{array}$ & $\begin{array}{l}\text { MODIS Mean (SD) } \\
\left(\mathrm{gC} \mathrm{m}^{-2} \mathrm{y}^{-1}\right)\end{array}$ & $\mathbf{r} \pm \mathbf{C L} \mathbf{L}^{1}$ & t-statistic ${ }^{1}$ & p-value ${ }^{2}$ \\
\hline Evergreen Needleleaf Forest & 8 & & & & & \\
\hline MODIS GPP with DAO Meteorology vs. Tower GPP & & $750(148)$ & $918(170)$ & & 3.886 & 0.006 \\
\hline MODIS GPP with Tower Meteorology vs. Tower GPP & & $750(148)$ & $692(97)$ & & 2.798 & 0.027 \\
\hline Mixed Forest & 20 & & & & & \\
\hline MODIS GPP with DAO Meteorology vs. Tower GPP & & $1277(509)$ & $1263(235)$ & $0.793 \pm 0.249$ & 6.885 & $<0.0001$ \\
\hline MODIS GPP with Tower Meteorology vs. Tower GPP & & $1277(509)$ & $1124(175)$ & & 4.928 & $<0.001$ \\
\hline Deciduous Broadleaf Forest & 20 & & & & & \\
\hline MODIS GPP with DAO Meteorology vs. Tower GPP & & $1565(38)$ & $1258(89)$ & & & \\
\hline MODIS GPP with Tower Meteorology vs. Tower GPP & & $1565(38)$ & $1189(179)$ & & & \\
\hline Open Shrubland & 20 & & & & & \\
\hline MODIS GPP with DAO Meteorology vs. Tower GPP & & $233(164)$ & $529(392)$ & & & \\
\hline MODIS GPP with Tower Meteorology vs. Tower GPP & & $233(164)$ & $362(164)$ & & & \\
\hline Savanna & 20 & & & & & \\
\hline MODIS GPP with DAO Meteorology vs. Tower GPP & & $642(256)$ & $748(198)$ & & & \\
\hline MODIS GPP with Tower Meteorology vs. Tower GPP & & $642(256)$ & $311(33)$ & & & \\
\hline Grassland & 20 & & & & & \\
\hline MODIS GPP with DAO Meteorology vs. Tower GPP & & $272(\mathrm{~N} / \mathrm{A})$ & 272 (N/A) & & & \\
\hline MODIS GPP with Tower Meteorology vs. Tower GPP & & 272 (N/A) & 294 (N/A) & & & \\
\hline
\end{tabular}

(Class 16) categories included in the current classification by the MOD12Q1 product. The Willow Creek site is also anomalous because there are a number of cropland pixels in the $7 \times 7 \mathrm{~km}$ MODIS extraction window surrounding the tower. While there are some wetland areas nearby which may be impacting the results, site investigators have found that the area surrounding the flux tower is dominated by deciduous broadleaf forest, with no cropland in the vicinity. The Duke Forest site misclassification also falls under the category of heterogeneous land cover and management. While analysis of the MODIS land cover indicates that $94 \%$ of the MODIS pixels are forested, the $7 \times 7 \mathrm{~km}$ MODIS extraction window includes old field and hardwood forest vegetation, a clearcut area, portions of the city of Chapel Hill, NC, and the Orange County, $\mathrm{NC}$, municipal landfill. The investigators use a strict footprint analysis to ensure that measured fluxes originate from the pine forest. The Metolius young ponderosa pine site showed $8 \%$ of the area misclassified as shrub- or grassland, when, in fact, the areas were young pine forests where field measurements indicate about $40 \%$ of the cover was understory shrubs.

\section{LAI and Fraction of Absorbed PAR (MOD15)}

The MOD15A2 algorithm provides essential inputs to the MOD17 GPP/NPP algorithm. The fPAR is used to directly calculate the GPP of a pixel (1), while LAI is used to scale the respiration equations for NPP estimates. Errors in fPAR, then, will lead to incorrect estimates of GPP. Unfortunately, few tower sites currently provide seasonal estimates of LAI because of the logistical difficulty in making enough measurements spatially around the towers, and the effect of tree stems on the subcanopy measurements as solar zenith angle increases autumn through spring and as solar azimuth changes seasonally. Furthermore, very few tower sites measure site-specific fPAR at the scale necessary for comparison with MODIS results. The MODIS LAI is derived via radiative transfer methods [24], and since LAI and fPAR are generally related to each other, we assume that an overestimation of LAI would correspond to an overestimation of fPAR. This is potentially a greater issue at low LAI $\left(<2 \mathrm{~m}^{2} \cdot \mathrm{m}^{-2}\right)$ sites, when a small change in LAI corresponds to a large change in fPAR, assuming a Beer's Law relationship. At sites with higher LAI values, however, a large change in LAI corresponds to a small change in fPAR, and algorithm saturation occurs. Field-based estimates of LAI ranged from 0.6 to $5.3 \mathrm{~m}^{2} \cdot \mathrm{m}^{-2}$, with a mean of $3.8 \mathrm{~m}^{2} \cdot \mathrm{m}^{-2}$. Overall, $62.5 \%$ of the LAI estimates from MODIS lie within the specifications $\left( \pm 0.5 \mathrm{~m}^{2} \cdot \mathrm{m}^{-2}\right.$ of LAI) of the MOD15A2 algorithm (Fig. 6). The remaining MOD15A2-based LAI values overestimate site LAI measurements by a relative error of $9.6 \%$ to $323.6 \%$ (median $=30.3 \%$ ), with the largest RE for sites with LAIs ranging from 1.0 to $5.2 \mathrm{~m}^{2} \cdot \mathrm{m}^{-2}$ (median $=3.9 \mathrm{~m}^{2} \cdot \mathrm{m}^{-2}$ ).

The LAI estimates from MODIS are consistent by biome type relative to site-based measurement results (Table IV). MODIS LAI significantly overestimates site LAI at both low LAI ( $p=$ $0.004)$ and high LAI ( $p=<0.001)$ sites. Evergreen needleleaf forests have an average estimated MODIS LAI of $4.5( \pm 0.3)$ $\mathrm{m}^{2} \cdot \mathrm{m}^{-2}$, and an average measured LAI of $3.6( \pm 1.3) \mathrm{m}^{2} \cdot \mathrm{m}^{-2}$. Conversely, for open shrubland systems, the average estimated MODIS LAI is $2.2( \pm 0.7) \mathrm{m}^{2} \cdot \mathrm{m}^{-2}$, and average measured LAI 


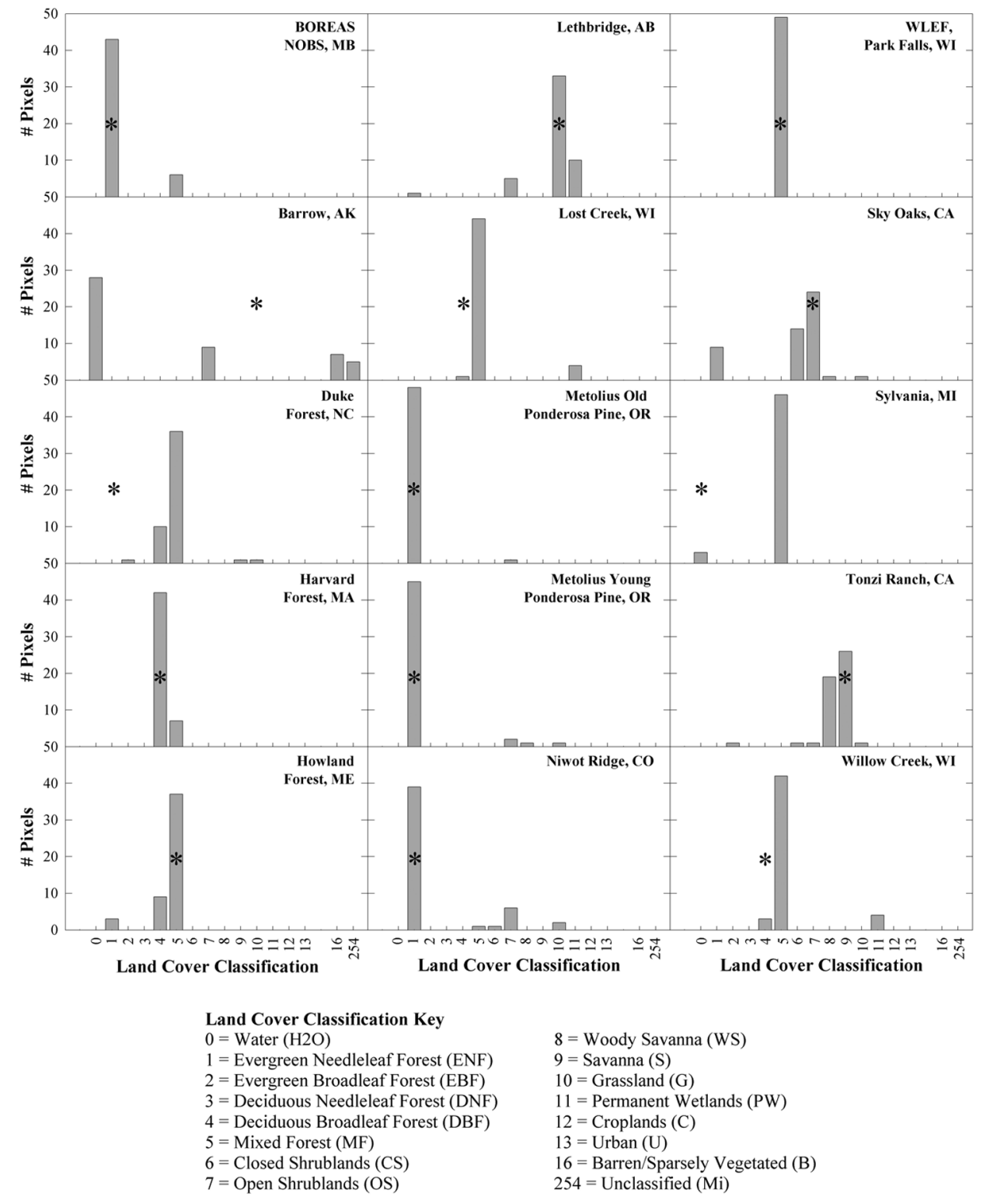

Fig. 5. Collection 3 University of Maryland (UMD) land cover classification for the fifteen sites. This land cover classification is used to determine the biome-specific biophysical properties used in the algorithm. Stars $(*)$ are used to indicate the actual land cover at each site.

is $1.1( \pm 0.1) \mathrm{m}^{2} \cdot \mathrm{m}^{-2}$. The savanna system is also overestimated, with an average estimated MODIS LAI of $4.3( \pm 0.3)$ $\mathrm{m}^{2} \cdot \mathrm{m}^{-2}$, and a measured LAI of $2.0 \mathrm{~m}^{2} \cdot \mathrm{m}^{-2}$.

\section{E. Seasonal Relationships in GPP}

One of the strengths of the MODIS GPP algorithm is its ability to capture seasonal dynamics in photosynthetic production. Seasonal traces of flux estimates for several flux tower sites indicate that the algorithm captures the onset and end of the growing season [Fig. 7(a), (c), and (d)]. In addition, the algorithm captures changes in photosynthesis throughout the growing season, indicating that it is responding to short-term changes in environmental conditions, although the magnitude of the changes may not be accurate. Use of tower meteorological data in the MODIS algorithm tends to overcorrect for these changes, which could be due in part to the fact that the algorithm has been designed specifically for use with the global DAO data. There are areas such as the Tonzi Ranch oak savanna site, however, in which the algorithm fails to capture all seasonal dynamics [Fig. 7(b)]. Both of the MODIS estimates capture the seasonal onset of growth during the winter and early spring as well as the return of the rainy season in November at this site. Use of the DAO meteorology in the MODIS algorithm captures trends at the Tonzi Ranch site better than the use of tower meteorology, but it fails to capture the decrease in production during the late summer when the site is extremely water limited. Use of tower data results in a complete shutdown of the algorithm for much of the year because of the high local VPD, indicating that the algorithm fails to account for vegetation that has adapted to this Mediterranean climate. This is in sharp contrast to the Metolius old ponderosa pine site, which has lower annual rainfall, and at which the MOD17 algorithm adequately captures the 


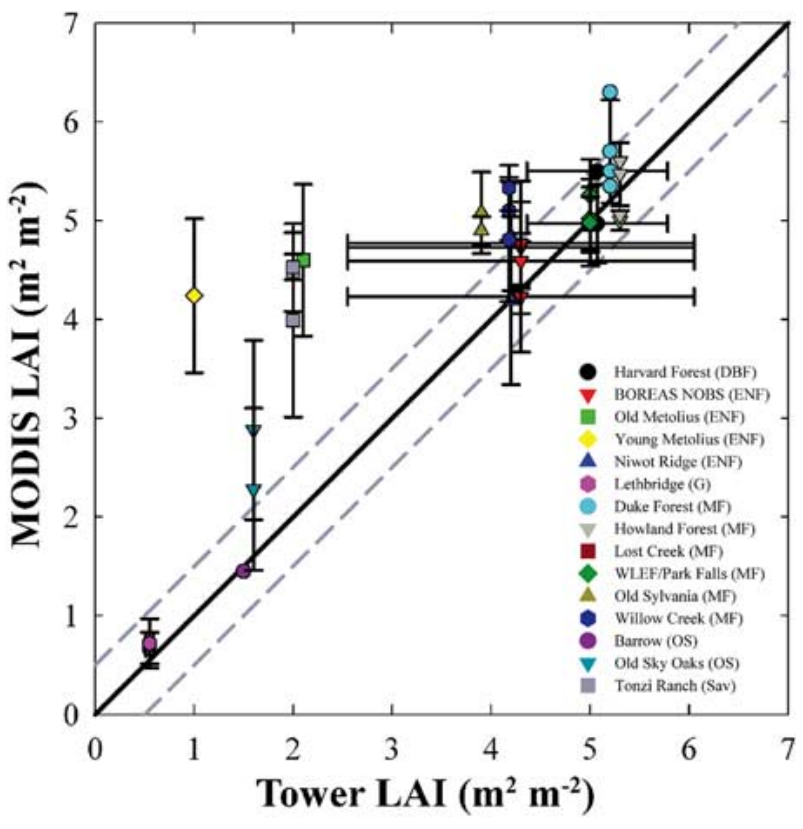

Fig. 6. Average LAI estimated for the tower pixel from the MOD15 algorithm as compared with site-specific LAI measurements. The dashed lines represent the specific acceptable variation in LAI computed with the algorithm $\left( \pm 0.5 \mathrm{~m}^{2} \mathrm{~m}^{-2}\right)$.

TABLE IV

COMPARISON OF Site LAI Estimates With Those From MODIS

\begin{tabular}{|c|c|c|c|c|c|}
\hline \multirow[b]{2}{*}{ Comparison } & \multicolumn{2}{|r|}{ Site LAI $\left(\mathrm{m}^{2} \mathbf{m}^{-2}\right)$} & MODIS LAI $\left(\mathbf{l n}^{2} \mathbf{~ n}^{-2}\right)$ & \multirow[b]{2}{*}{ t-statistic ${ }^{1}$} & \multirow[b]{2}{*}{ p-value ${ }^{2}$} \\
\hline & n & Mean (SD) & Mean (SD) & & \\
\hline Sites with Low LAI & 10 & $1.5(0.6)$ & $3.0(1.6)$ & -3.918 & 0.004 \\
\hline Sites with High LAI & 25 & $4.7(0.5)$ & $5.1(0.5)$ & -4.17 & $<0.001$ \\
\hline \multicolumn{6}{|c|}{$\begin{array}{l}{ }^{2} \text { Two-sided t-tests }(\alpha=0.0975) \text { are performed because criteria from the Shaprio-Wilkes normality } \\
\text { test are not adequate for correlation analysis. }\end{array}$} \\
\hline \multicolumn{6}{|c|}{${ }^{2}$ Values are deemed significantly different from each other when $\alpha \leq 0.0975$. } \\
\hline \multicolumn{6}{|l|}{ b. } \\
\hline Biome Type & & $\begin{array}{l}\text { Site LAI }\left(\mathrm{m}^{2} \mathbf{m}^{-2}\right) \\
\quad \text { Mean (SD) }\end{array}$ & $\begin{array}{l}\text { MODIS LAI }\left(\mathrm{m}^{2} \mathrm{~m}^{-2}\right) \\
\text { Mean (SD) }\end{array}$ & & \\
\hline \multicolumn{6}{|l|}{ Evergreen } \\
\hline Needleleaf Forest & & $3.6(1.3)$ & $4.5(0.3)$ & & \\
\hline Open Shrubland & & $1.1(0.1)$ & $2.2(0.7)$ & & \\
\hline Savamna & & $2(\mathrm{~N} / \mathrm{A})$ & $4.3(0.3)$ & & \\
\hline
\end{tabular}

seasonal changes in GPP. Additional research is needed at other drought-affected sites to determine if this is a site-specific limitation of the algorithm, or if it has impacts at the larger scale.

Since all of the sites in this study are located in North America, the year is arbitrarily divided into four seasons, each containing three months of data.

1) Spring (March-May): Spring is the time of growing season onset, and there is a relatively rapid transition in ecosystem processes during leaf-out. Because of the eight-day compositing period used with many MODIS products, it is not surprising that some of the greatest differences between tower and MODIS estimates of GPP occur during this period, particularly in early spring [Table II and Fig. 8(a)]. However, there is not a clear pattern to the relationship when considering either climate or biome type effects (Fig. 8). Most sites are significantly overestimated $(p<0.0001)$, although a few sites are underestimated when compared with tower estimates. The use of tower meteorology in the MOD17 algorithm does not resolve GPP overestimation relative to tower-based results at
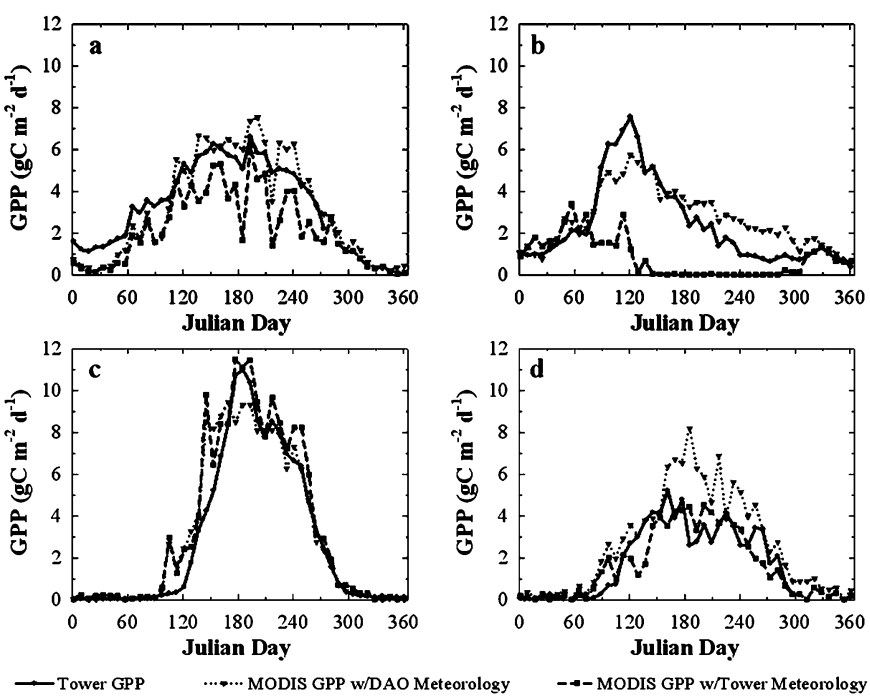

-Tower GPP

....... MODIS GPP w/DAO Meteorology

--- MODIS GPP w/Tower Meteorology

Fig. 7. Seasonal traces of GPP estimated from tower $\mathrm{CO}_{2}$ flux data and for MODIS GPP calculated using both DAO and tower-specific meteorology for four AmeriFlux tower sites. (a) Metolius (old growth ponderosa pine). (b) Tonzi Ranch (oak savanna). (c) Sylvania (old growth deciduous broadleaf). (d) Niwot Ridge (subalpine fir).

most sites, and causes under estimation at two sites (Duke Forest and Tonzi Ranch).

2) Summer (June-August): The best relationships between tower and MODIS GPP occur during summer (Table II). Because overstory canopies are in full flush during this time, there should be less uncertainty assigned to the MOD15 algorithm as a result of the compositing period. Analysis of maximum LAI of the tower site and the MOD15 algorithm (Fig. 6) reveals that MODIS has a consistent bias toward overestimation of LAI, and presumably, of fPAR as well. There is still a bias toward MODIS overestimation of GPP relative to tower based estimates at these sites $(\mathrm{RE}=38 \% ; p<0.0001)$ when using the DAO meteorology in the MOD17 algorithm [Fig. 9(a)]. The use of tower meteorology in the MOD17 algorithm [Fig. 9(b)] reduces bias $(\mathrm{RE}=-4 \%)$, but the difference between the tower and MODIS GPP remains significant $(p<0.0001)$ as variation in the results increases. Because summer is the time of primary growth and production, the errors associated with summertime estimates of GPP will dominate the annual pattern.

3) Autumn (September-November): Autumn results using the interpolated DAO meteorology are fairly well-correlated with tower estimates of GPP $(r=0.800 \pm 0.203)$. However, the total autumn MODIS GPP for most of the sites is $\sim 200 \mathrm{gC} \cdot \mathrm{m}^{-2}$, and sites with low productivity tend to be overestimated in the autumn, while sites with relatively higher productivity tend to be slightly underestimated relative to tower based estimates ( $\mathrm{RE}=69 \%$; Fig. 10). The use of tower meteorology in MOD17 removes some of this bias $(\mathrm{RE}=38 \%$ ), although the difference from tower GPP is significant $(p<0.0001)$.

4) Winter (January-February and December): Winter is a time of low productivity at most of the study sites (Fig. 11), and MODIS and tower-based GPP are again well correlated $(\mathrm{r}=$ $0.819 \pm 0.194)$. While the MOD17 algorithm estimates similar production $\left(\sim 100 \mathrm{gC} \cdot \mathrm{m}^{-2}\right)$ for a number of sites that range 

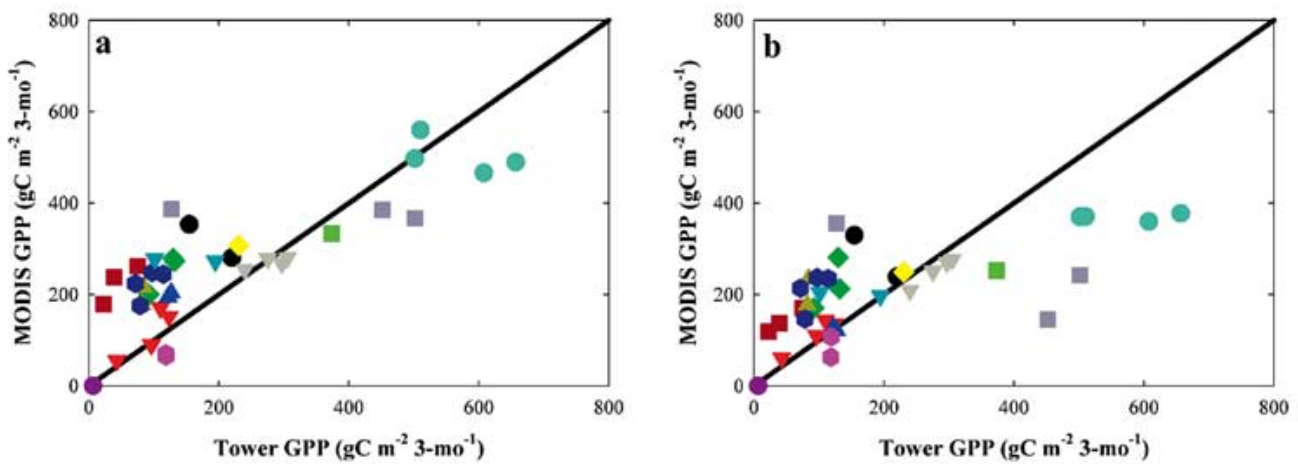

- Harvand Forest (DBF)

BOREAS NOBS (ENF)

Old Metolius (ENF)

Young Metolius (ENF)

A Niwot Ridge (ENF)

- Lethbridge (G)

Duke Forest (MF)

Howland Forest (MF)

Vowland Forest (MF)

- Lost Creek (MF)

A Old Sylvania (MF)

- Willow Creek (MF)

- Barrow (OS)

$\checkmark$ Old Sky Oaks (OS)

Vonzi Ranch (Sav)

Fig. 8. Comparisons of tower GPP for Spring (March-May) with MODIS GPP estimated using (a) DAO meteorology and (b) tower-specific meteorology.
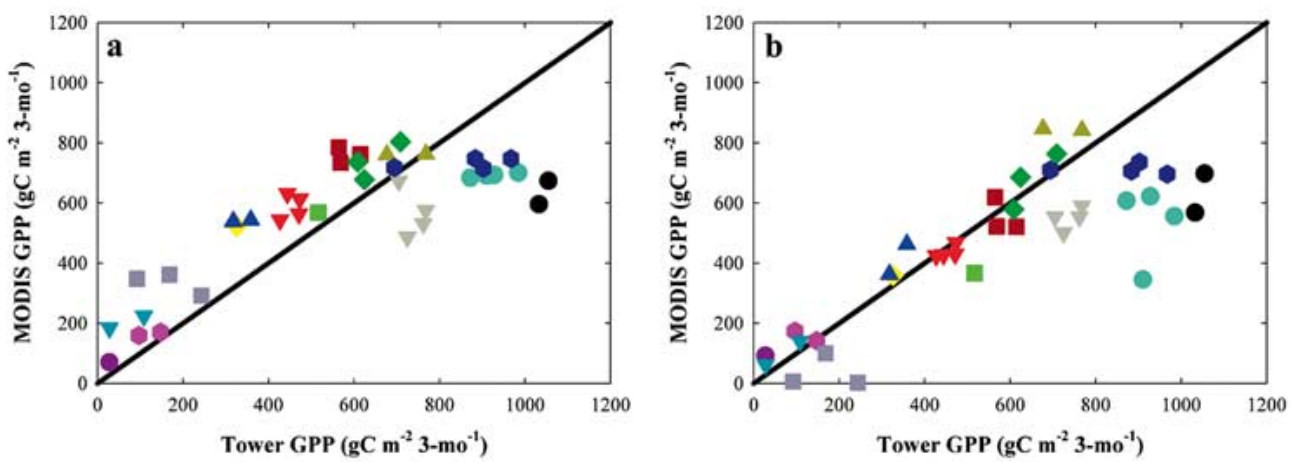

Harvard Forest (DBF) BOREAS NOBS (ENF) Old Metolius (ENF)

Young Metolius (ENF)

A Niwot Ridge (ENF)

Lethbridge (G)

Duke Forest (MF)

- Dowland Forest (MF)

Howland Forest (MF)

- Lost Creek (MF)

Old Sylvania (MF)

Willow Creck (MF)

- Barrow (OS)

Old Sky Oaks (OS)

- Tonzi Ranch (Sav)

Fig. 9. Same as Fig. 8, but for Summer (June-August).
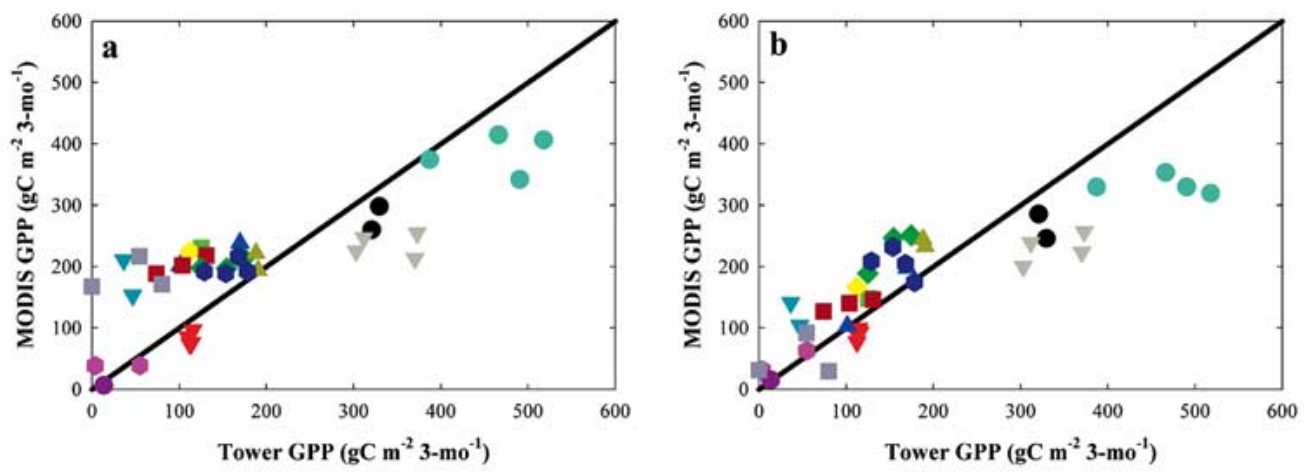

Harvard Forest (DBF) BOREAS NOBS (ENF)

Old Metolius (ENF)

Young Metolius (ENF)

A Niwot Ridge (ENF)

- Lethbridge (G)

- Duke Forest (MF)

7. Howland Forest (MF)

- Lost Creek (MF)

- WLEF/Park Falls (MF)

A. Old Sylvania (MF)

- Willow Creck (MF)

- Barrow (OS)

V. Old Sky Oaks (OS)

Fig. 10. Same as Fig. 8, but for Autumn (September-November).
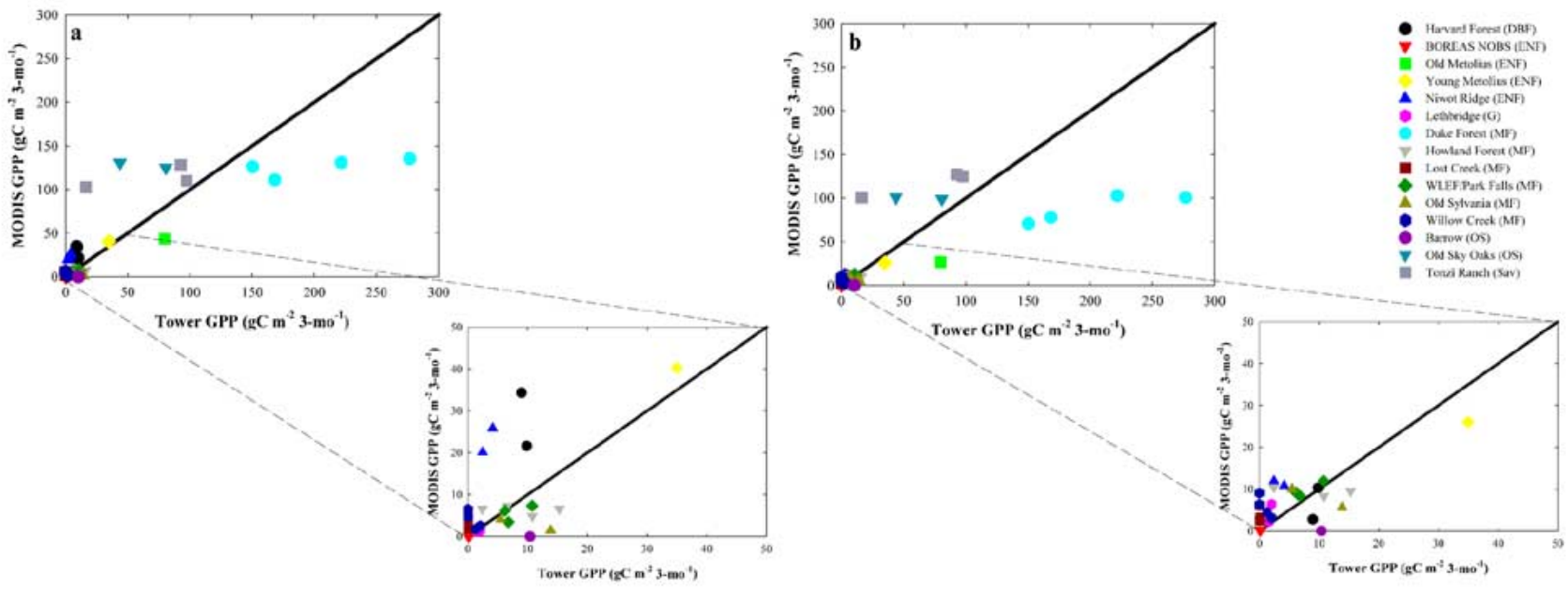

Fig. 11. Same as Fig. 8, but for Winter (January-February and December). 
in productivity from near 0 to almost $300 \mathrm{gC} \cdot \mathrm{m}^{-2}$, there is insufficient supplemental site data to quantitatively determine the reason for these differences. Use of tower meteorology in the MOD17 GPP algorithm does not significantly alter the slope of the trend line, but correlation is reduced $(r=0.746 \pm 0.225)$.

\section{Discussion}

There are a number of possible reasons for the differences in tower and MODIS estimates of GPP. For the purposes of this generalized study, we are necessarily assuming that tower GPP and meteorology are ground truthed, but there are errors associated with these measurements. Tower GPP is calculated as the difference between NEE and Reco. Estimates of ecosystem respiration at flux tower sites are typically made using nighttime fluxes of NEE (when photosynthesis is assumed to be zero). Calm winds often occur at night, and the data are screened from the analysis ( $\mathrm{a} \mathrm{u}^{*}$ filter is commonly used), limiting the dataset that can be used to estimate GPP (GPP = daytime NEE + daytime ecosystem respiration). However, there may be situations in which the above-canopy fluxes are decoupled from the surface, leading to underestimates of nighttime respiration and, thus, GPP that arise from both systematic and random errors [42]-[46]. Also, tower flux footprints are subsamples of the MODIS pixel, often less than $1 \mathrm{~km}$. In heterogeneous areas, the differing scales of the tower and MODIS GPP estimates should ideally be taken into account via an upscaling process, such as that used in the Bigfoot study [15]-[17]. Unfortunately, the upscaling technique is both intensive and expensive, and, as such, cannot be used at a large number of sites. In addition, site conditions can make it more difficult to obtain estimates of GPP. For example, the low productivity and harsh weather found at the Barrow site make it difficult to accurately capture seasonal and annual GPP and Reco components of net $\mathrm{CO}_{2}$ flux measurements.

Probably the single largest error associated with MODIS GPP at most sites derives from the meteorology. The MOD17 algorithm is strongly dependent on VPD to reduce the maximum radiation use efficiency (1), and, therefore, underestimation of VPD contributes greatly to the overestimation of GPP. The VPD at which the radiation use efficiency begins to be reduced in the MODIS BPLUT is on the order of 650 to $1100 \mathrm{~Pa}$ [20]. As the DAO meteorology underestimates local VPD at many dry sites during the summer [47], it does not sufficiently constrain photosynthesis in the MOD17 algorithm during dry periods. Furthermore, since the MOD17 algorithm does not directly account for soil moisture, there may be problems at water-limited sites, as the results from Tonzi Ranch suggest. The local vegetation is well-adapted to the dry summer drought-like conditions and associated large maximum VPD values for local (5500 Pa) and regional DAO (3400 Pa) typical of these sites. While both of these maximum VPD values would result in a complete shutdown of photosynthesis in the MOD17 algorithm, consistent underestimation of the VPD by the DAO compared to actual local meteorology partially explains the MODIS overestimation of GPP (RE $=30 \%$ ) for days 180-300 at Tonzi Ranch [Fig. 4(f) and Table III]. The use of tower meteorology overcorrects for the problem, causing the algorithm to underestimate the GPP of the site $(\mathrm{RE}=-46 \%)$, suggesting that this site warrants further investigation.

Land cover is a potential source of error because of the heterogeneity of the landscape at the subpixel scale. In general, however, the land cover classification is fairly accurate; research has demonstrated that the MODIS land cover product is accurate to within $82 \%$ [26]. Our study has found that many of the misclassifications within the MODIS land cover tend to occur within similar classes, reducing potential errors in GPP estimates.

The land cover map captures the dominant cover types at sites with three notable exceptions. The area surrounding the Barrow, AK, site is dominated by wet sedge tundra, but is described by MODIS as either shrubland or barren/sparsely vegetated. Since the $\varepsilon$ for open shrubland in MOD17 is higher than that for grasslands under similar environmental conditions and the MODIS GPP is not calculated for the barren areas, the resulting MODIS GPP is artificial. Site estimates, however, match those of the flux tower fairly closely, indicating that there are compensatory errors at this site, which may include the difficulty in obtaining site data and errors in the MOD15 product. The Willow Creek site is also anomalous because there are a number of cropland pixels in the $7 \times 7 \mathrm{~km}$ MODIS extraction window surrounding the tower. These pixels, which exhibit radically different GPP behavior than adjacent forest, would strongly influence aggregate GPP estimates at this site. Many of the extant land cover types surrounding the Duke Forest (the pine plantation considered here, old field, hardwood forest, and urban) are smaller than $1 \times 1 \mathrm{~km}$ and are aggregated as "mixed forest" by the C3 MODIS land cover classification. Remote sensing data with greater resolution in the spatial domain, for example IKONOS, may be necessary to capture fluxes from highly productive and extremely heterogeneous landscapes [48]. Unfortunately, such specialized analyzes would also limit the global applicability of the MODIS algorithm.

It is difficult to quantify the error associated with the LAI/fPAR product in this study because of the limited availability of site-specific measurements. The LAIs at more than half of the study sites are within the design specification of the MOD15 product, although the remainder were overestimated. This corresponds to the results of Cohen et al. [15], who found that MODIS LAI overestimated site measurements of LAI at four sites in four different biomes. There are additional on-going studies to verify the LAI and fPAR products [23], [40], [49], [50]. These results will provide valuable information on the errors associated with both LAI and fPAR.

The MODIS LAI and fPAR measurements used in this study were required to pass the quality control checks of the MOD17 algorithm, reducing potential cloud and snow contamination. However, it is possible that some contamination remains, particularly at high latitudes in which low solar angles, persistent cloud cover, and extended periods of darkness can affect reflectance readings from the optical MODIS sensor. This signal contamination could affect GPP in undetermined ways. Consistent overestimation of GPP in the spring suggests that there is a problem with early season estimation of fPAR, which could be the result of a combination of cloudy skies and snowmelt. 
Discovery of the true effects of fPAR in spring will require extensive instrumentation, which is beyond the scope of the current study. Further, missing LAI/fPAR measurements are gap filled using a simple linear function. During the active growing season, most gaps were small, increasing the accuracy of the interpolation method. Gaps during the nongrowing season were more common because of cloud cover and contamination by snow and ice. This fact has a large impact on the seasonal analysis of the data, but less of an impact at the annual timescale. Estimates at sites with large data gaps may be erroneous, particularly if the gaps occur during times of rapid transition, such as spring and autumn. The MODIS LAI/fPAR measurements at Barrow, AK, were difficult to obtain because of meteorological conditions at the site, resulting in 18 missing datapoints during the study period, with the largest gap (nine continuous measurements) occurring at the beginning of the growing season. It was also difficult to obtain accurate estimates of LAI and fPAR at the Harvard Forest site, which had large data gaps during the growing season in both 2001 (ten points) and 2002 (nine points). These results could explain, in part, the differences between site and MODIS data.

A possible contribution to the overestimation of LAI is the way in which it is measured. Sites typically only provide LAI measurements of the dominant, overstory canopy, while the MODIS sensor receives reflectance information for a vertically and horizontally integrated canopy. If the dominant canopy is open, as it is at many of these sites, the MOD15 algorithm will consider both overstory and understory surface reflectance as a single canopy unit of the land cover classification, leading to overestimation of LAI relative to site-based measurements. In deciduous broadleaf forests where the understory may flush out earlier in the season. If the forest also contains evergreen needleleaf trees, such as Harvard Forest (10\% ENF), the algorithm will calculate an LAI and fPAR for a DBF forest canopy prior to actual leaf-out. At Metolius evergreen needleleaf sites, both understory and overstory LAI were measured in the field at 20 1-ha plots [51], and the MOD15 LAI greatly overestimated the total LAI of these sites (RE of 50\%-100\%), suggesting that sites with open canopies should be considering the understory contribution to LAI, GPP and NEE.

The MODIS GPP algorithm does not have a winter dormancy function to regulate winter productivity. Therefore, if the MOD15 algorithm reports a sizable LAI and FPAR for a site, and temperatures are not limiting, it is possible for the MODIS algorithm to calculate photosynthesis during that time. Alternately, the Duke Forest is classified as a mixed forest, but is actually dominated by loblolly pine (Pinus taeda). This site can maintain relatively high GPP in the winter under mild weather conditions, indicating that a winter dormancy function cannot be used globally.

The fPAR tends to saturate in areas with high LAI values, limiting its ability to capture the activity of highly productive sites such as Duke Forest. Alternately, MODIS overestimates the LAI of the savanna site, which could lead to an increased MODIS GPP estimate and explain, in part, the differences between the MODIS and tower-derived GPP. In addition, measurements made by the BigFoot study group indicate that the fPAR is overestimated at the Barrow site throughout the growing season, while it is overestimated mid-season at the Metolius forest site [52]. Finally, studies need to be performed to determine the accuracy of the fPAR product for a senescing canopy or a canopy experiencing prolonged water stress, and to quantify the true effects of MODIS LAI/fPAR on GPP estimates.

The MODIS algorithm itself is a source of error in estimating GPP. One of the largest assumptions made is for a constant maximum radiation use efficiency for all sites within a given biome. However, one can easily imagine that the RUE of a boreal forest is not the same as that of a southern U.S. warm-temperate planted pine forest, leading to overestimations at the boreal forest and underestimations at the warmer site. It is also possible that the algorithm does not accurately account for VPD and temperature effects with the generalized scalars. However, this is a global product, which is produced every eight days, and certain simplifying assumptions are necessary to ensure that reasonably accurate results are produced in a fairly rapid fashion for all vegetated MODIS pixels.

\section{CONCLUSION}

The MODIS GPP algorithm has been developed to provide a consistent, continuous global estimate of photosynthetic production. The resulting dataset is evaluated for 38 site years of data, comparing tower site estimates of GPP with those from the MODIS algorithm. Use of the global DAO meteorology is problematic because of the scale of the product $\left(1.00^{\circ} \times 1.25^{\circ}\right)$. There is a $28 \%$ difference between the MODIS GPP derived with DAO meteorology and the MODIS GPP derived with tower-specific meteorology. The resulting tower-specific estimates of MODIS GPP are not significantly different from the GPP estimates calculated from site measurements of NEE. This indicates that the DAO data can be a significant source of error in the MOD17 algorithm. The VPD is the primary source of error from the DAO, and the relative impact of this error on MODIS GPP increases as limitations from VPD become more severe.

Additional errors, while difficult to quantify in this type of general analysis, propagate from the MODIS products used in the GPP algorithm. The MOD12 land cover product can affect the GPP output in two ways. It is used in the MOD15 LAI and fPAR product algorithm and is used to specify the biome type, and, hence, a set of ecophysiological parameters, for the MOD17 GPP product. The MOD12 land cover accurately captures the MOD15-associated land cover, which is based on vegetation structural type. The MOD12 algorithm is less accurate at capturing the land cover for the MOD17 Biome Properties Look-Up Table. However, most of the differences are within the forest classes themselves, resulting in less error than would occur by misclassifying land cover morphology (e.g., forest versus grassland). The largest error associated with land cover is the assumption of a single land cover class for the entire 1-km pixel. This is not a valid assumption at many sites and may need to be addressed in future research efforts.

Outputs from the MOD15 LAI/fPAR algorithm are another potential source of error for MODIS GPP calculations. The MOD17 algorithm uses a strict quality assurance control over MOD15 product inputs to eliminate potential contamination 
from clouds and other adverse effects, but there are still problems in the winter in areas containing snow and ice. In addition, the MOD15 algorithm tends to overestimate the LAI at most of the study sites, particularly early in the spring, and this could lead to an associated overestimation of MODIS GPP relative to the site. It is not possible at this time to fully quantify the effects of the MOD15 algorithm, but its effects on MODIS GPP estimates should be considered in the future when adequate data are available for analysis. More site-specific measurements are needed to determine the accuracy of the fPAR product directly including seasonal measurements of overstory and understory LAI and fPAR.

Errors associated with the MOD17 GPP algorithm itself cannot be ignored. Further research is needed to clarify the relative contributions of uncertainty in the various assumptions of ecological response parameters represented in the BPLUT component of the MOD17 algorithm. In some cases, the maximum conversion use efficiency may be underestimated (e.g., Duke Forest). With an increasing network of sensors at AmeriFlux network eddy covariance towers, the radiation use efficiency and the parameters within the BPLUT that control the associated $T_{\min }$ and VPD reductions can be evaluated. It is also likely that spatial heterogeneity in stand-age, soil type, and canopy structure is not well represented by a global land cover map containing only eleven different vegetation types and the associated BPLUT. Currently, the algorithm calculates GPP based on a single overstory vegetation type. This simplification leads to overestimations of GPP in complex ecosystems, particularly in areas with LAIs of $2.5 \mathrm{~m}^{2} \cdot \mathrm{m}^{-2}$ or less. The MODIS vegetation continuous fields product currently in development may improve the MODIS GPP product [53]. The continuous fields product will provide subpixel proportional estimates of the basic vegetation forms (e.g., tree, shrub, evergreen, deciduous, etc.), which can then be used in conjunction with the BPLUT to determine a more accurate GPP, as all of the vegetation types within a pixel can be taken into account in calculations. Errors at several of the other sites, such as the Tonzi Ranch savanna and Duke Forest, require additional investigation.

Meteorology and land cover do not completely explain the differences between MODIS and tower-based GPP estimates, suggesting the importance of evaluating the algorithm. Turner et al. [16], [17], as part of the BigFoot MODIS validation project, have provided valuable insight regarding potential improvements to the MOD17 algorithm, including accounting for possible PAR saturation effects on the conversion efficiency and the improved representation of seasonal variability in light use efficiency. There is additional evidence to suggest that, while many studies show a quasilinear relationship between light use efficiency and GPP [54], [55], this assumption may not be valid for all vegetation types [56], [57]. On the other hand, nonlinear light response curves tend to become more linear if they are evaluated over the course of a day [58]. Differences in the light use efficiencies of sunlit and shaded leaves are not explicitly considered in the satellite-based approach. Soil water and nutrient limitations are also not explicitly defined in the algorithm. These factors may also help explain the MODIS overestimates of GPP as compared with tower results.
The results of this study indicate, however, that the current MODIS GPP algorithm shows reasonable spatial patterns and temporal variability across a diverse range of biomes and climate regimes. So, while continued efforts are needed to isolate particular problems in specific biomes, we are optimistic about the general quality of these data. While no individual dataset can be expected to meet all of the individual needs of the climate change community, continuation of the MOD17 GPP product will likely provide a key component of global terrestrial ecosystem analysis, providing continuous weekly measurements of global vegetation production.

\section{ACKNOWLEDGMENT}

The authors would like to thank C. Boisvenue, The University of Montana, for providing valuable assistance with the statistical analysis. They would also like to thank W. M. Jolly, USDA Forest Service Rocky Mountain Research Station Fire Sciences Laboratory, Missoula, MT, for providing programming support for this analysis. The initital results of this analysis were reviewed at the Fluxnet 2003 Tahoe Synthesis Workshop.

\section{REFERENCES}

[1] J. T. Houghton, Y. Ding, D. J. Griggs, M. Noguer, P. J. van der Linden, X. Dai, K. Maskell, and C. A. Johnson, Eds., "Climate Change 2001: The Scientific Basis. Contribution of Working Group 1 to the Third Assessment Report of the Intergovernmental Panel on Climate Change," IPCC, 2001.

[2] P. A. Stott, S. F. B. Tett, G. S. Jones, M. R. Allen, J. F. B. Mitchell, and G. J. Jenkins, "External control of 20th century temperature by natural and anthropogenic forcings," Science, vol. 290, pp. 2133-2137, 2000.

[3] S. Fan, M. Gloor, J. Mahlman, S. Pacala, J. Sarmiento, T. Takahoshi, and P. Tans, "A large terrestrial carbon sink in North America implied by atmospheric and oceanic carbon dioxide data and models," Science, vol. 282, pp. 442-446, 1998.

[4] S. C. Wofsy, M. L. Goulden, J. W. Munger, S. M. Fan, P. S. Bakwin, B. C. Daube, S. L. Bassow, and F. A. Bazzaz, "Net exchange of carbon dioxide in a mid-latitude forest," Science, vol. 260, pp. 1314-1317, 1993.

[5] C. C. Barford, S. C. Wofsy, M. L. Goulden, J. W. Munger, E. H. Pyle, S. P. Urbanski, L. Hutyra, S. R. Saleska, D. Fitzjarrald, and K. Moore, "Factors controlling long- and short-term sequestration of atmospheric $\mathrm{CO}_{2}$ in a mid-latitude forest," Science, vol. 294, pp. 1688-1691, 2001.

[6] B. H. Braswell, D. S. Schimel, S. Linder, and B. Moore, III, "The response of global terrestrial ecosystems to interannual temperature variability," Science, vol. 278, pp. 870-872, 1997.

[7] J. T. Randerson, C. B. Field, I. Y. Fung, and P. P. Tans, "Increases in early season ecosystem uptake explain recent changes in the seasonal cycle of atmospheric $\mathrm{CO}_{2}$ at high northern latitudes," Geophys. Res. Lett., vol. 26, pp. 2765-2768, 1999.

[8] C. O. Justice, E. Vermote, J. R. G. Townshend, R. DeFries, D. P. Roy, D. K. Hall, V. V. Salomonson, J. L. Privette, G. Riggs, A. Strahler, W. Lucht, R. B. Myneni, Y. Knyazikhin, S. W. Running, R. R. Nemani, Z. W, A. R. Huete, W. van Leeuwen, R. E. Wolfe, L. Giglio, J.-P. Muller, P. Lewis, and M. J. Barnsley, "The moderate resolution imaging spectroradiometer (MODIS): Land remote sensing for global change research," IEEE Trans. Geosci. Remote Sens., vol. 36, no. 4, pp. 1228-1249, Jul. 1998.

[9] C. B. Field, M. J. Behrenfeld, J. T. Randerson, and P. Falkowski, "Primary production of the biosphere: Integrating terrestrial and oceanic components," Science, vol. 281, pp. 237-240, 1998.

[10] C. B. Field, J. T. Randerson, and C. M. Malström, "Global net primary production: Combining ecology and remote sensing," Remote Sens. Environ., vol. 51, pp. 74-88, 1995.

[11] R. R. Nemani, C. D. Keeling, H. Hashimoto, W. M. Jolly, S. C. Piper, C. J. Tucker, R. B. Myneni, and S. W. Running, "Climate-driven increases in global terrestrial net primary production from 1982 to 1999," Science, vol. 300, pp. 1560-1563, 2003. 
[12] S. D. Prince and S. N. Goward, "Global primary production: A remote sensing approach," J. Biogeography, vol. 22, pp. 815-835, 1995.

[13] A. Ruimy and B. Saugier, "Methodology for the estimation of terrestrial net primary production from remotely sensed data," J. Geophys. Res., vol. 99, pp. 5263-5283, 1994.

[14] D. Schimel, "Terrestrial biogeochemical cycles: Global estimates with remote sensing," Remote Sens. Environ., vol. 51, pp. 49-56, 1995.

[15] W. B. Cohen, T. K. Maiersperger, Z. Yang, S. T. Gower, D. P. Turner, W. D. Ritts, M. Berterretche, and S. W. Running, "Comparisons of land cover and LAI estimates derived from ETM+ and MODIS for four sites in North America: A quality assessment of 2000/2001 provisional MODIS products," Remote Sens. Environ., vol. 88, pp. 233-255, 2003.

[16] D. P. Turner, W. D. Ritts, W. B. Cohen, S. T. Gower, M. Zhao, S. W. Running, S. C. Wofsy, S. Urbanski, A. L. Dunn, and J. W. Munger, "Scaling gross primary production (GPP) over boreal and deciduous forest landscapes in support of MODIS GPP product validation," Remote Sens. Environ., vol. 88, pp. 256-270, 2003.

[17] D. P. Turner, S. Urbanski, D. Bremer, S. C. Wofsy, T. Meyers, S. T. Gower, and M. Gregory, "A cross-biome comparison of daily light use efficiency for gross primary production," Global Change Biol., vol. 9, pp. 383-395, 2003.

[18] J. L. Monteith, "Solar radiation and productivity in tropical ecosystems," J. Appl. Ecol., vol. 9, pp. 747-766, 1972.

[19] - "Climate and the efficiency of crop production in Britain," Philosoph. Trans. Roy. Soc. Lond. B, vol. 281, pp. 277-294, 1977.

[20] F. A. Heinsch, M. C. Reeves, P. Votava, S. Kang, C. Milesi, M. Zhao, J. Glassy, W. M. Jolly, R. Loehman, C. F. Bowker, J. S. Kimball, R. R. Nemani, and S. W. Running, User's Guide: GPP and NPP (MOD17A2/A3) Products, NASA MODIS Land Algorithm. Missoula, MT: Univ. Montana, 2003, p. 57.

[21] S. W. Running, R. R. Nemani, F. A. Heinsch, M. Zhao, M. C. Reeves, and H. Hashimoto, "A continuous satellite-derived measure of global terrestrial primary production," BioScience, vol. 54, pp. 547-560, 2004.

[22] S. W. Running, P. E. Thornton, R. R. Nemani, and J. M. Glassy, "Global terrestrial gross and net primary productivity from the Earth Observing System," in Methods in Ecosystem Science, O. Sala, R. Jackson, and H. Mooney, Eds. New York: Springer-Verlag, 2000, pp. 44-57.

[23] R. B. Myneni, S. Hoffman, Y. Knyazikhin, J. L. Privette, J. Glassy, Y. Tian, Y. Wang, X. Song, Y. Zhang, G. R. Smith, A. Lotsch, M. Friedl, J. T. Morisette, P. Votava, R. R. Nemani, and S. W. Running, "Global products of vegetation leaf area and fraction absorbed PAR from year one of MODIS data," Remote Sens. Environ., vol. 83, pp. 214-231, 2002.

[24] R. B. Myneni, R. R. Nemani, and S. W. Running, "Estimation of global leaf area index and absorbed PAR using radiative transfer models," IEEE Trans. Geosci. Remote Sens., vol. 35, no. 6, pp. 1380-1393, Nov. 1997.

[25] R. Myneni, Y. Knyazikhin, J. Glassy, P. Votava, and N. Shabanov, User's Guide: FPAR, LAI (ESDT:MOD15A2) 8-Day Composite NASA MODIS Land Algorithm. Boston, MA: Boston Univ., 2003.

[26] M. C. Hansen, R. S. DeFries, J. R. G. Townshend, and R. Sohlberg, "Global land cover classification at $1 \mathrm{~km}$ spatial resolution using a classification tree approach," Int. J. Remote Sens., vol. 21, pp. 1331-1364, 2000.

[27] M. A. White, P. E. Thornton, S. W. Running, and R. R. Nemani, "Parameterization and sensitivity analysis of the BIOME-BGC terrestrial ecosystem model: Net primary production controls," Earth Interactions, vol. 4, pp. 1-84, 2000.

[28] P. E. Thornton, "Regional ecosystem simulation: Combining surfaceand satellite-based observations to study linkages between terrestrial energy and mass budgets," in School of Forestry. Missoula, MT: Univ. Montana, 1998, p. 280

[29] J. S. Kimball, P. E. Thornton, M. A. White, and S. W. Running, "Simulating forest productivity and surface-atmosphere carbon exchange in the BOREAS study region," Tree Physiol., vol. 17, pp. 589-599, 1997.

[30] M. Zhao, F. A. Heinsch, R. R. Nemani, and S. W. Running, "Improvements of the MODIS terrestrial gross and net primary production global dataset," Remote Sens. Environ., vol. 95, pp. 164-176, 2005.

[31] E.-D. Schulze, F. M. Kelliher, C. Korner, C. R. Lloyd, J. Lloyd, and R. Leuning, "Relationships among maximum stomatal conductance, ecosystem surface conductance, carbon assimilation rate, and plant nitrogen nutrition: A global ecology scaling exercise," Annu. Rev. Ecol. Syst., vol. 25, pp. 629-660, 1994.
[32] DAO, "Data Assimilation Office (DAO) Algorithm Theoretical Basis Document (ATBD)", Data Assimilation Office, Goddard Space Flight Center, Greenbelt, MD, 2002.

[33] S. D. Schubert, R. B. Rood, and J. Pfaendtner, "An assimilated dataset for Earth science applications," Bull. Amer. Meteorol. Soc., vol. 74, pp. 2331-2342, 1993.

[34] D. Baldocchi, E. Falge, L. Gu, R. Olson, D. Hollinger, S. W. Running, P. Anthoni, C. Bernhofer, K. Davis, R. Evans, J. Fuentes, A. Goldstein, G. Katul, B. Law, X. Lee, Y. Malhi, T. Meyers, W. Munger, W. Oechel, U. K. T. Paw, K. Kilegaard, H. P. Schmid, R. Valentini, S. Verma, T. Vesala, K. Wilson, and S. Wofsy, "FLUXNET: A new tool to study the temporal and spatial variability of ecosystem-scale carbon dioxide, water vapor, and energy flux densities," Bull. Amer. Meteorol. Soc., vol. 82, pp. 2415-2434, 2001.

[35] M. Reichstein, J. D. Tenhunen, O. Roupsard, J.-M. Ourcival, S. Rambal, F. Miglietta, A. Peressotti, M. Pecchiari, G. Tirone, and R. Valentini, "Severe drought effects on ecosystem $\mathrm{CO}_{2}$ and $\mathrm{H}_{2} \mathrm{O}$ fluxes at three Mediterranean evergreen sites: Revision of current hypotheses?," Global Change Biol., vol. 8, pp. 999-1017, 2002.

[36] A. R. Desai, P. V. Bolstad, B. D. Cook, K. J. Davis, and E. V. Carey, "Comparing net ecosystem exchange of carbon dioxide between an oldgrowth and mature forest in the upper Midwest, USA," Agricult. Forest Meteorol., vol. 128, pp. 33-55, 2005.

[37] B. D. Cook, K. J. Davis, W. Wang, A. Desai, B. W. Berger, R. M. Teclaw, J. G. Martin, P. V. Bolstad, P. S. Bakwin, C. Yi, and W. Heilman, "Carbon exchange and venting anomalies in an upland deciduous forest in northern Wisconsin, USA," Agricult. Forest Meteorol., vol. 126, pp. 271-295, 2004.

[38] E. Falge, D. Baldocchi, R. Olson, P. Anthoni, M. Aubinet, C. Bernhofer, G. Burba, R. Ceulemans, R. Clement, H. Dolman, A. Granier, P. Gross, T. Grünwald, D. Hollinger, N. O. Jensen, G. Katul, P. Keronen, A. Kowalski, C. T. Lai, B. E. Law, T. Meyers, J. Moncrieff, E. Moors, J. W. Munger, K. Pilegaard, Ü. Rannik, C. Rebmann, A. Suyker, J. Tenhunen, K. Tu, S. Verma, T. Vesala, K. Wilson, and S. Wofsy, "Gap filling strategies for defensible annual sums of net ecosystem exchange," Agricult. Forest Meteorol., vol. 107, pp. 43-69, 2001.

[39] M. A. Friedl, D. K. McIver, J. C. F. Hodges, X. Y. Zhang, D. Muchoney, A. H. Strahler, C. E. Woodcock, S. Gopal, A. Schneider, A. Cooper, A. Baccini, F. Gao, and C. Schaaf, "Global land cover mapping from MODIS: Algorithms and early results," Remote Sens. Environ., vol. 83, pp. 287-302, 2002.

[40] M. Friedl, Personal Communication, Boston Univ., Boston, MA, May 2004.

[41] A. Lotsch, Y. Tian, M. A. Friedl, and R. B. Myneni, "Land cover mapping in support of LAI/FPAR retrievals from EOS MODIS and MISR. Classification methods and sensitivities to errors," Int. J. Remote Sens., vol. 24, pp. 1997-2016, 2003.

[42] M. Aubinet, B. Heinesch, and B. Longdoz, "Estimation of the carbon sequestration by a heterogeneous forest: Night flux corrections, heterogeneity of the site and inter-annual variability," Global Change Biol., vol. 8, pp. 1053-1071, 2002.

[43] B. W. Berger, K. J. Davis, C. Yi, P. S. Bakwin, and C. L. Zhao, "Longterm carbon dioxide fluxes from a very tall tower in a northern forest: Flux measurement methodology," J. Atmos. Ocean. Technol., vol. 18, pp. 529-542, 2001.

[44] J. Moncrieff, R. Valentini, S. Greco, G. Seufert, and P. Ciccioli, "Trace gas exchange over terrestrial ecosystems: Methods and perspectives in micrometeorology," J. Exp. Bot., vol. 48, pp. 1133-1142, 1997.

[45] J. B. Moncrieff, Y. Malhi, and R. Leuning, "The propagation of errors in long-term measurements of land-atmosphere fluxes of carbon and water," Global Change Biol., vol. 2, pp. 231-240, 1996.

[46] E. Falge, D. Baldocchi, J. Tenhunen, M. Aubinet, P. Bakwin, P. Berbigier, C. Bernhofer, G. Burba, R. Clement, K. J. Davis, J. A. Elbers, A. H. Goldstein, A. Grelle, A. Granier, J. Guomundsson, D. Hollinger, A. S. Kowalski, G. Katul, B. E. Law, Y. Malhi, T. Meyers, R. K. Monson, J. W. Munger, W. Oechel, U. K. T. Paw, K. Pilegaard, Ü. Rannik, C. Rebmann, A. Suyker, R. Valenti, K. Wilson, and S. Wofsy, "Seasonality of ecosystem respiration and gross primary production as derived from FLUXNET measurements," Agricult. Forest Meteorol., vol. 113, pp. 75-95, 2002.

[47] M. Zhao, S. W. Running, and R. R. Nemani, "Sensitivity of MODIS terrestrial primary production to the accuracy of meteorological reanalyzes," J. Geophys. Res., to be published.

[48] T. M. Scanlon and J. D. Albertson, "Water availability and the spatial complexity of $\mathrm{CO}_{2}$, water, and energy fluxes over a heterogeneous sparse canopy," J. Hydrometeorol., vol. 4, pp. 798-809, 2003. 
[49] Y. Tian, C. E. Woodcock, Y. Wang, J. L. Privette, N. V. Shabanov, L. Zhou, Y. Zhang, W. Buermann, J. Dong, B. Veikkanen, T. Häme, K. Andersson, M. Ozdogan, Y. Knyazikhin, and R. B. Myneni, "Multiscale analysis and validation of the MODIS LAI product. I. Uncertainty assessment," Remote Sens. Environ., vol. 83, pp. 414-430, 2002.

[50] _ - "Multiscale analysis and validation of the MODIS LAI product. II. Sampling strategy," Remote Sens. Environ., vol. 83, pp. 431-441, 2002.

[51] B. E. Law, S. Van Tuyl, A. Cescatti, and D. D. Baldocchi, "Estimation of leaf area index in open-canopy ponderosa pine forests at different successional stages and management regimes in Oregon," Agricult. Forest Meteorol., vol. 108, pp. 1-14, 2001.

[52] D. P. Turner, W. D. Ritts, W. B. Cohen, T. K. Maeirsperger, S. T. Gower, A. A. Kirschbaum, S. W. Running, M. Zhao, S. C. Wofsy, A. L. Dunn, B. E. Law, J. L. Campbell, W. C. Oechel, H. Kwon, T. P. Meyers, E. E. Small, S. A. Kurc, and J. A. Gamon, "Site-level evaluation of satellitebased global terrestrial GPP and NPP monitoring," Global Change Biol., to be published.

[53] M. C. Hansen, R. S. DeFries, J. R. G. Townshend, M. Carroll, C. Dimiceli, and R. A. Sohlberg, "Global percent tree cover at a spatial resolution of 500 meters: First results of the MODIS vegetation continuous fields algorithm," Earth Interactions, vol. 7, pp. 10.1175/1087-3562(2003)007, 2003

[54] A. Ruimy, P. G. Jarvis, D. D. Baldocchi, and B. Saugier, "Carbon dioxide fluxes over plant canopies and solar radiation: A review," Adv. Ecol. Res., vol. 26, pp. 1-68, 1995.

[55] D. Baldocchi, "A comparative study of mass and energy exchange rates over a closed $\mathrm{C}_{3}$ (wheat) and an open $\mathrm{C}_{4}$ (corn) crop: II. $\mathrm{CO}_{2}$ exchange and water use efficiency," Agricult. Forest Meteorol., vol. 67, pp. 291-321, 1994.

[56] D. Y. Hollinger, F. M. Kelliher, J. N. Byers, J. E. Hunt, T. M. McSeveny, and P. L. Weir, "Carbon dioxide exchange between an undisturbed old-growth temperate forest and the atmosphere," Ecology, vol. 75, pp. 134-150, 1994.

[57] S. M. Fan, M. L. Goulden, J. W. Munger, B. C. Daube, P. S. Bakwin, S. C. Wofsy, J. S. Amthor, D. R. Fitzjarrald, K. E. Moore, and T. R. Moore, "Environmental controls on the photosynthesis and respiration of a boreal lichen woodland, A growing season of whole-ecosystem exchange measurements by eddy correlation," Oecologia, vol. 102, pp. 443-452, 1995.

[58] R. Leuning, F. M. Kelliher, D. de Pury, and E.-D. Schulze, "Leaf nitrogen, photosynthesis, conductance and transpiration: Scaling from leaves to canopies," Plant, Cell, Environ., vol. 18, pp. 1183-1200, 1995.

[59] K. V. R. Schäfer, R. Oren, D. S. Ellsworth, C. T. Lai, J. D. Herrick, A. C. Finzi, D. D. Richter, and G. G. Katul, "Exposure to an enriched $\mathrm{CO}_{2}$ atmosphere alters carbon assimilation and allocation in a pine forest ecosystem," Global Change Biol., vol. 9, pp. 1378-1400, 2003.

[60] D. Y. Hollinger, J. Aber, B. Dail, E. A. Davidson, S. M. Goltz, H. Hughes, M. Y. Leclerc, J. T. Lee, A. D. Richardson, C. Rodrigues, N. A. Scott, D. Achuatavarier, and J. Walsh, "Spatial and temporal variability in forest-atmosphere $\mathrm{CO}_{2}$ exchange," Global Change Biol., vol. 10, pp. 1689-1706, 2004

[61] D. Y. Hollinger, S. M. Goltz, E. A. Davidson, J. T. Lee, K. Tu, and H. T. Valentine, "Seasonal patterns and environmental control of carbon dioxide and water vapor exchange in an ecotonal boreal forest," Global Change Biol., vol. 5, pp. 891-902, 1999.

[62] L. B. Flanagan, L. A. Wever, and P. J. Carlson, "Seasonal and interannual variation in carbon dioxide exchange and carbon balance in a northern temperate grassland," Global Change Biol., vol. 8, pp. 599-615, 2002.

[63] L. A. Wever, L. B. Flanagan, and P. J. Carlson, "Seasonal and interannual variation in evapotranspiration, energy balance and surface conductance in a northern temperate grassland," Agricult. Forest Meteorol., vol. 112, pp. 31-49, 2002.

[64] P. M. Anthoni, M. H. Unsworth, B. E. Law, J. Irvine, D. Baldocchi, and D. Moore, "Seasonal differences in carbon and water vapor exchange in young and old-growth ponderosa pine ecosystems," Agricult. Forest Meteorol., vol. 111, pp. 203-222, 2002.

[65] B. E. Law, P. E. Thornton, J. Irvine, P. M. Anthoni, and S. Van Tuyl, "Carbon storage and fluxes in ponderosa pine forests at different developmental stages," Global Change Biol., vol. 7, pp. 755-777, 2001.

[66] R. K. Monson, A. A. Turnipseed, J. P. Sparks, P. C. Harley, L. E. ScottDenton, K. Sparks, and T. E. Huxman, "Carbon sequestration in a highelevation, subalpine forest," Global Change Biol., vol. 8, pp. 459-178, 2002.

[67] A. A. Turnipseed, P. D. Blanken, D. E. Anderson, and R. K. Monson, "Energy budget above a high-elevation subalpine forest in complex topography," Agricult. Forest Meteorol., vol. 110, pp. 177-201, 2002.
[68] M. L. Goulden, B. C. Daube, S. M. Fan, D. J. Sutton, A. Bazzaz, J. W Munger, and S. C. Wofsy, "Physiological responses of a black spruce forest to weather," J. Geophys. Res., vol. 102, pp. 28 987-28 996, 1997.

[69] M. L. Goulden, S. C. Wofsy, J. W. Harden, S. E. Trumbore, P. M. Crill, S. T. Gower, T. Fries, B. C. Daube, S.-M. Fan, D. J. Sutton, A. Bazzaz, and J. W. Munger, "Sensitivity of boreal forest carbon balance to soil thaw," Science, vol. 279, pp. 214-217, 1998.

[70] K. J. Davis, C. Zhao, R. M. Teclaw, J. G. Isebrands, P. S. Bakwin, C. $\mathrm{Yi}$, and B. W. Berger, "The annual cycles of $\mathrm{CO}_{2}$ and $\mathrm{H}_{2} \mathrm{O}$ exchange over a northern mixed forest as observed from a very tall tower," Global Change Biol., vol. 9, pp. 1278-1293, 2003.

[71] H. Luo, W. C. Oechel, H. Kwon, and Y. Qian, "Net ecosystem exchange of carbon and water vapor in a southern California chaparral ecosystem,' presented at the Ecology, Conservation and Management of Mediterranean Climate Ecosystems Conf., Rhodes, Greece, 2004.

[72] D. D. Baldocchi, L. Xu, and N. Kiang, "How plant functional-type, weather, seasonal drought, and soil physical properties alter water and energy fluxes of an oak-savanna and an annual grassland," Agricult. Forest Meteorol., vol. 123, pp. 13-39, 2004. 